筑 波 大 学

博 士 (医学) 学 位 論 文 


\section{Extracellular adenosine and slow-wave sleep are increased after ablation of nucleus accumbens core astrocytes and neurons in mice. \\ （マウスにおける側坐核コア領域のアスト ロサイトと神経細胞の除去は、細胞外ア デノシンと徐波睡眠を増やす。）}

2019

筑波大学大学院博士課程人間総合科学研究科

\section{ZHOU XUZHAO}




\section{Table of Contents}

\section{Introduction}

1.1 Adenosine and its involvement in sleep regulation

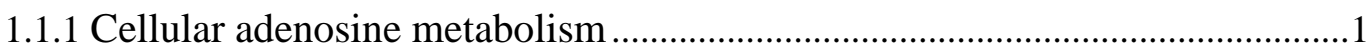

1.1.2 The properties of adenosine receptors …….......................................................

1.1.3 Associations between adenosine levels and sleep ...........................................5

1.2 The Nucleus accumbens and its role in sleep regulation ....................................6

1.2.1 The anatomical properties of the NAc …….......................................................6

1.2.2 The NAc plays an important role in sleep/wake regulation

1.3 Astrocyte, a promising source of extracellular adenosine ..................................10

1.4 Diphtheria toxin and its novel applications in research .....................................11

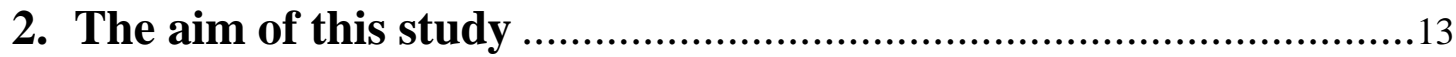

\section{Materials and methods}

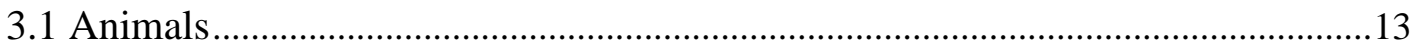

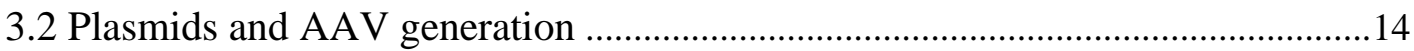

3.3 Stereotaxic AAV injection, EEG/EMG recordings and vigilance state assessment

3.4 Microdialysis in freely behaving mice and measurement of adenosine by HPLC

3.5 Histology .18

3.6 Statistical analysis

\section{Results}

4.1 SWS increased after cytotoxic ablation of NAc GFAP-positive cells.

4.2 Cytotoxic ablation of NAc GFAP-positive cells led to increased activation of astrocytes and microglia

4.3 Extracellular adenosine levels increased after ablation of NAc GFAP-positive cells

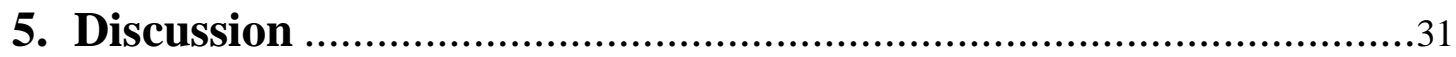




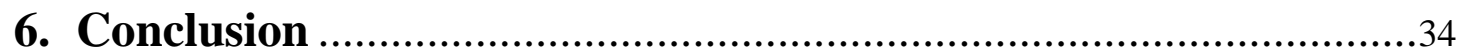

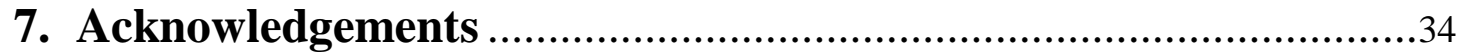

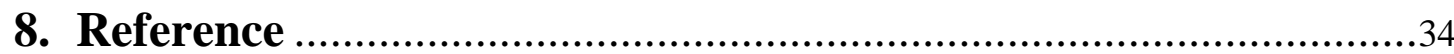

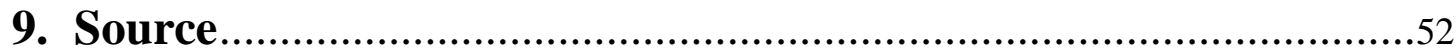




\section{List of Abbreviations}

\begin{tabular}{|c|c|}
\hline AAV & adeno-associated virus \\
\hline aca & anterior commissure \\
\hline ADA & adenosine deaminase \\
\hline AdK & adenosine kinase \\
\hline $\mathrm{ADP}$ & adenosine diphosphate \\
\hline AMP & adenosine monophosphate \\
\hline Amyg & basolateral amygdala \\
\hline ANOVA & analysis of variances \\
\hline ATP & adenosine triphosphate \\
\hline BBB & blood brain barrier \\
\hline $\mathrm{BF}$ & basal forebrain \\
\hline cAMP & cyclic adenosine monophosphate \\
\hline Cas9 & CRISPR-associated protein-9 nuclease \\
\hline CPA & $\mathrm{N}^{6}$-cyclopentyladenosine \\
\hline $\mathrm{CPT}$ & 8-cyclopentyltheophylline \\
\hline $\mathrm{CPu}$ & caudate putamen \\
\hline CRISPR & clustered regularly interspaced short palindromic repeats \\
\hline DAPI & $4^{\prime}, 6$-diamidino-2-phenylindole \\
\hline dnSNARE & $\begin{array}{l}\text { dominant negative soluble } \mathrm{N} \text {-ethylmaleimide-sentitive factor attachment } \\
\text { protein receptor }\end{array}$ \\
\hline DT & diphtheria toxin \\
\hline DTA & diphtheria toxin fragment A \\
\hline DTR & diphtheria toxin receptor \\
\hline EEG & electroencephalogram \\
\hline EMG & electromyogram \\
\hline ENT & equilibrative nucleoside transporters \\
\hline
\end{tabular}




\begin{tabular}{|c|c|}
\hline EYFP & enhanced yellow fluorescent protein \\
\hline FFT & fast-Fourier transform \\
\hline GABA & $\gamma$-aminobutyric acid \\
\hline GFAP & glial fibrillary acidic protein \\
\hline hGH poly A & human growth hormone polyadenylation site \\
\hline hM4 & human M4 muscarinic receptor \\
\hline HPLC & high performance liquid chromatography \\
\hline IIIS & International Institute for Integrative Sleep Medicine \\
\hline i.p. & intraperitoneal \\
\hline ITR & inverted terminal repeat sequence \\
\hline KO & knock out \\
\hline mGFAP & mouse glial fibrillary acidic protein \\
\hline $\mathrm{mPFC}$ & medial prefrontal cortex \\
\hline MSN & medium spiny neurons \\
\hline NAc & nucleus accumbens \\
\hline NT & nucleotidases \\
\hline $\mathrm{P} 2 \mathrm{~A}$ & 2A self-cleaving peptide \\
\hline pAAV & plasmid adeno-associated virus \\
\hline PBS & phosphate buffered saline \\
\hline PBT & phosphate buffered saline containing $0.25 \%$ Triton $X-100$ \\
\hline PCR & polymerase chain reaction \\
\hline PKA & protein kinase $\mathrm{A}$ \\
\hline PLSD & Fisher's protected least significant difference \\
\hline PVT & paraventricular thalamus \\
\hline $\mathrm{R}$ & receptor \\
\hline REM & rapid eye movement \\
\hline $\mathrm{SAH}$ & S-adenosylhomocysteine \\
\hline $\mathrm{SNc}$ & Substantia nigra pars compacta \\
\hline SWA & slow-wave activity \\
\hline SWS & slow-wave sleep \\
\hline
\end{tabular}


TBI

traumatic brain injury

TMN tuberomammillary nucleus

vHipp ventral hippocampus

VP ventral pallidum

VTA ventral tegmental area

WPRE woodchuck hepatitis virus post-transcriptional regulatory element 


\section{Introduction}

\subsection{Adenosine and its involvement in sleep regulation}

Adenosine is a purine nucleoside structured as an adenine attached to a $\beta$-Dribofuranose moiety. Its derivatives are widespread in nature and some of them have important roles in biochemical processes, such as energy transfer as ATP and ADP or signal transduction as cAMP. According to current knowledge, adenosine regulates cellular activity by acting on four evolutionarily well-conserved metabotropic receptors: the purinergic $\mathrm{G}$ protein-coupled $\mathrm{A}_{1}, \mathrm{~A}_{2 \mathrm{~A}}, \mathrm{~A}_{2 \mathrm{~B}}$, and $\mathrm{A}_{3}$ receptors. Adenosine is not a neurotransmitter or a typical neuromodulator, because its formation can be increased by various processes in all cell types, and in all cell parts. It is well established that adenosine modulates sleep by acting at $\mathrm{A}_{1}$ or $\mathrm{A}_{2 \mathrm{~A}}$ receptors. Evidence suggests that $A_{2 A} R$ suppress wakefulness to induce sleep, i.e., induce sleep gating, however, $A_{1} R$ predominantly mediate sleep need.

\subsubsection{Cellular adenosine metabolism}

Metabolism of adenosine is well studied and established (Figure 1, Zhou \& Lazarus. Adenosinergic control of sleep/wake behavior. Handbook of Sleep Research, 2019, in press). Basically adenosine is formed during the hydrolysis of AMP or SAH (Fredholm, 2007; Schrader, 1983). It can be formed from SAH by the enzyme SAH hydrolase, which can also act to convert adenosine when there is excess L-homocysteine. This process happens intracellularly and the enzyme bi-directionally maintains constant presence of a defined concentration of adenosine in the cell, even though the contribution of SAH hydrolase to the generation of adenosine in the brain seems not significant (Latini \& 
Pedata, 2001). On the other hand, adenosine can be generated both intracellularly and extracellularly from $5^{\prime}$-AMP by $5^{\prime}-\mathrm{NT}$, mediated by a set of different enzymes (Zimmermann, 2000). In extracellular environment, an ecto-5'-NT is part of a cascade (together with ecto-ATPases) that terminates nucleotide actions such as ATP as a signaling molecule (Kovacs et al., 2013; Yegutkin, 2008; Zimmermann, 2000, 2006).

Adenosine concentrations can be controlled by the depleting enzyme ADA when they are high enough, and by reuptake effects (Fredholm et al., 2005; Oishi et al., 2008; Parkinson et al., 2011). The adenosine re-absorbed by cells is rapidly phosphorylated to AMP by AdK which is an enzyme that effectively regulates the intracellular adenosine concentration. The equilibrative nucleoside transporters can bi-directionally modulate the concentration of adenosine (Dos Santos-Rodrigues, Grane-Boladeras, Bicket, \& Coe, 2014; Parkinson et al., 2011). Therefore, the production and depletion of extracellular adenosine regulate its concentrations. In the normal baseline conditions, extracellular adenosine levels are low which are calculated as approximately 30 to $300 \mathrm{nM}$ (Ballarin et al., 1991). In some special diseases or environments like mild hypoxia or strenuous exercise, extracellular adenosine levels can be up to $1 \mu \mathrm{M}$ or more. Moreover, in severely traumatic situations, including severe local ischemia, the levels can even be several tens of micromolar (Fredholm, 2007). 


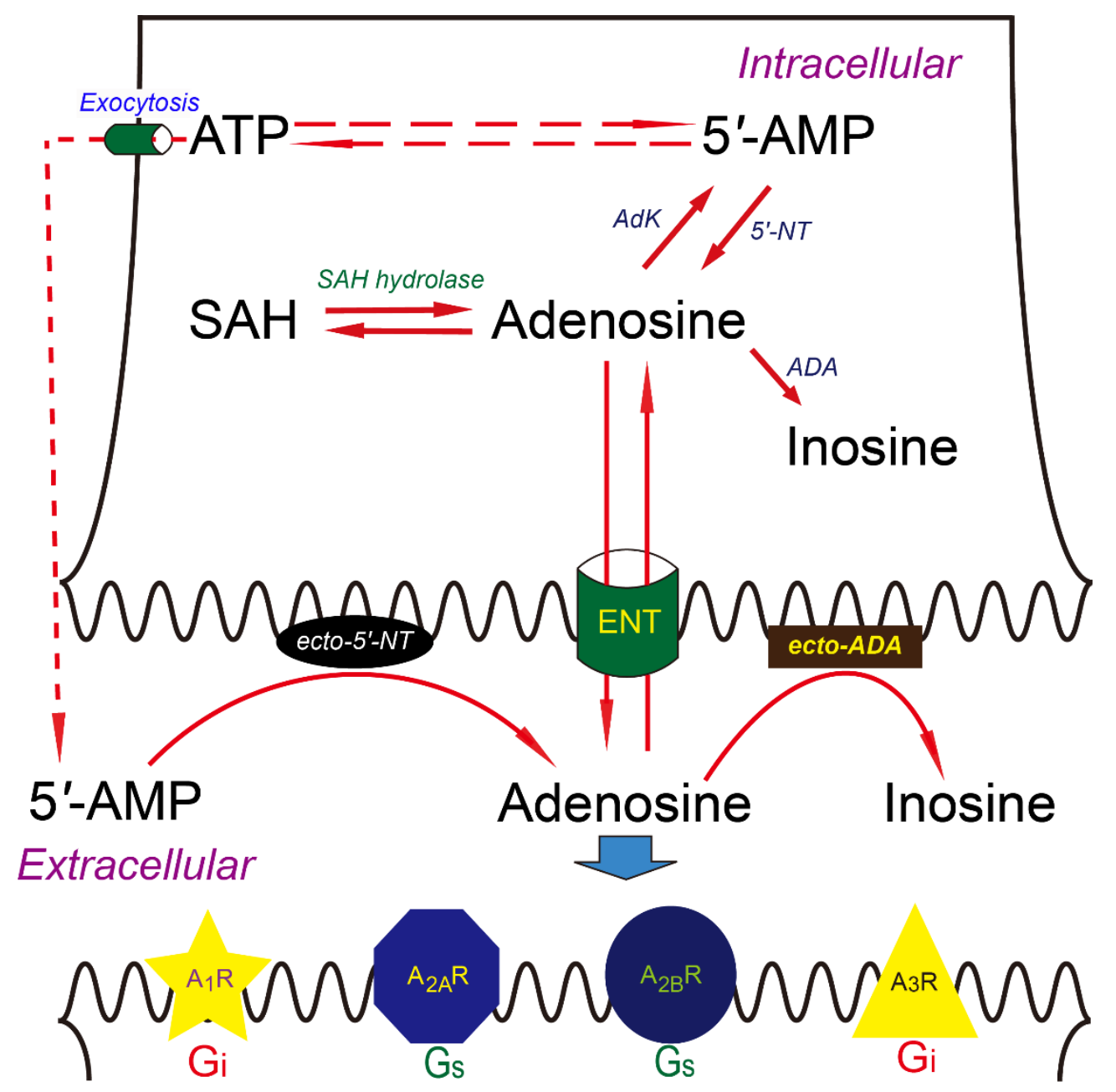

Figure 1. Schematic representation of adenosine metabolism. Adenosine is produced by intracellular or extracellular conversion of 5'-AMP catalyzed by 5'-NT or by hydrolysis of SAH catalyzed by SAH hydrolase. Adenosine levels are regulated by ADA or adenosine kinase AdK by conversion to inosine or 5'-AMP, respectively. Equilibrative nucleoside transporters (ENT) bi-directionally regulate the concentration of adenosine available to cell surface $A_{1}, A_{2 A}, A_{2 B}$, and $A_{3}$ receptors $\left(A_{1} R, A_{2 A} R, A_{2 B} R\right.$, and $\left.A_{3} R\right)$. (Modified from Zhou \& Lazarus. Adenosinergic control of sleep/wake behavior. Handbook of Sleep Research, 2019, in press)

\subsubsection{The properties of adenosine receptors}

Extracellular adenosine exerts effects when it binds on one of the four types of receptors:

$A_{1} R, A_{2 A} R, A_{2 B} R$, and $A_{3} R$ (Fredholm et al., 2011). $A_{1} R$ and $A_{3} R$ are coupled with inhibitory $G_{i}$ proteins, by contrast, $A_{2 A} R$ and $A_{2 B} R$ are coupled with excitatory $G_{s}$ proteins (Fredholm et al., 2005). Activation of $A_{1} R$ or $A_{3} R$ inhibits adenylate cyclase 
activity, followed by decreased production of cAMP from ATP. This in turn down regulates the activity of cAMP-dependent protein kinase and cAMP response element binding protein phosphorylation. Therefore, Gi-coupled receptor is inhibitory to cells. In contrast, activation of $\mathrm{A}_{2 \mathrm{~A}} \mathrm{R}$ or $\mathrm{A}_{2 \mathrm{~B}} \mathrm{R}$ enhances the cAMP production and cAMPdependent protein kinase activity, together with cAMP response element binding protein phosphorylation, functioning as cell stimulation (Cunha, 2001; Fredholm et al., 2011; Paes-de-Carvalho, 2002).

The receptors for adenosine are distributed throughout the whole body in mammals. $A_{1} R$ are widely distributed, which has the highest abundance in the brain despite a low-density expression (Daly \& Padgett, 1992). Interestingly, $\mathrm{A}_{2 \mathrm{~A}} \mathrm{R}$ are expressed mainly in the respiratory and cardiovascular system, leukocytes, and the basal ganglia of the brain (Fredholm et al., 2001, 2011). $\mathrm{A}_{2 \mathrm{~B}} \mathrm{R}$ are expressed at low abundance throughout the body and $A_{3} R$ are differently expressed among species. For example, $A_{3} R$ of rats are highly enriched in the testis and mast cells, but in humans, $A_{3} R$ are mainly expressed in the lung and liver (Linden et al., 1993; Salvatore et al., 1993). Basal adenosine levels are able to activate its receptors under physiologic conditions except for the $A_{2 B} R$ which requires a higher concentration (Fredholm et al., 2011). Nevertheless, the effect of adenosine at low concentrations also depends on the abundance of receptors. In case of only a few receptors, effects are possible only in a high adenosine concentration. Currently, it is reported that $A_{1} R$ and $A_{2 A} R$ are involved in sleep regulation but the other two are not (Lazarus et al., 2017). 


\subsubsection{Associations between adenosine levels and sleep}

Adenosine was initially isolated for the first time from cardiac tissue extracts in 1929.More than 60 years have passed since the discovery of its hypnotic effect in the cat brain in 1954 (Drury \& Szent-Gyorgyi, 1929; Feldberg \& Sherwood, 1954). Similar somnogenic effects of adenosine were subsequently observed in a dogs, fowls, rats, and mice (Dunwiddie et al., 1982; Haulica et al., 1973; Marley et al., 1972; Radulovacki et al., 1984, 1985; Ticho et al., 1991). However, how adenosine regulates sleep, i.e, the brain cell types involved in the adenosinergic sleep-inducing effects, and the relative contributions of $A_{1} R$ and $A_{2 A} R$ to sleep/wake regulation remain unclear.

There is a hypothesis that adenosine actually stands for a state of relative energy deficiency. Therefore, early concepts of sleep/wake regulation assumed that the desire for sleep periodically is to replenish low energy stores, at least partially if not all. (Pull \& Mcilwain, 1972; Tobler \& Scherschlicht, 1990; Vanwylen et al., 1986). Actually, invivo microdialysis assays of extracellular adenosine levels in the hippocampus and neostriatum in freely-behaving rats revealed that adenosine levels are higher during the inactive period than the active period, which seems to be a strong support to this theory (Huston et al., 1996). Additionally, it is also hypothesized that extracellular adenosine levels allow the brain to assess the need for sleep. The discovery in rats suggests that systemic or intracerebroventricular administration of CPA, a selective $A_{1} R$ agonist, dosedependently increases SWA during sleep, similar to the response to sleep deprivation. SWA is a slow oscillatory neocortical activity (usually defined from 0.5 to $4.0 \mathrm{~Hz}$ ) that is increased following prolonged wakefulness but descends during sleep thus it is 
considered as a marker of sleep homeostasis, in other words, a balance between waking and sleep (Benington et al., 1995).

ATP depletion is positively correlated with an increase in extracellular adenosine levels (Kalinchuk et al., 2003) and sleep (Porkka-Heiskanen et al., 1997). Adenosine levels measured by in-vivo microdialysis from several brain areas in cats during spontaneous sleep-wake cycles were higher during sleep than wakefulness (Porkka-Heiskanen et al., 1997, 2000). These experiments also revealed a 2 -fold increase in adenosine levels in the $\mathrm{BF}$ during a prolonged $6 \mathrm{~h}$ wakefulness compared with levels at the beginning of sleep deprivation (Porkka-Heiskanen et al., 1997, 2000). Therefore, adenosine is thought to control $B F$ neurons via $A_{1} R$ since $A_{1} R$ mRNA is significantly increased in the $B F$ after sleep deprivation. Besides, perfusion of adenosine or the $\mathrm{A}_{1} \mathrm{R}$ agonist cyclohexyladenosine into the $\mathrm{BF}$ induces sleep by inhibiting wake-active neurons, whereas the $A_{1} R$ antagonist CPT induces wakefulness (Basheer et al., 2000, 2001).

Furthermore, pharmacological studies found that inhibition of ADA, AdK, and equilibrative nucleoside transporters leads to sleep due to increased extracellular adenosine levels (Oishi et al., 2008; Okada et al., 2003; Porkka-Heiskanen et al., 1997; Radulovacki et al., 1983). These results established a strong correlation between adenosine metabolism and sleep.

\subsection{The Nucleus accumbens and its role in sleep regulation}

\subsubsection{The anatomical properties of the NAc}

The NAc is a nucleus located in the ventral striatum (Figure 2), containing core and 
shell subunits which are composed of GABAergic projection neurons (about 95\% MSNs and 1 2\% interneurons) and cholinergic interneurons (about 1 2\%) (George Paxinos \& Keith Franklin, 2001; Robison \& Nestler, 2011). Basically, the MSNs in the NAc can also be sorted into direct and indirect pathway neurons which can be distinguished by the expression of dopamine $D_{1} R$ or $D_{2} R$ respectively. The two kinds of heterogeneous MSNs play complementary but sometimes opposite roles in modulating brain functions and behaviors. Moreover, the MSNs of the direct pathway co-express the excitatory $\mathrm{D}_{1} \mathrm{R}$ and inhibitory adenosine $\mathrm{A}_{1} \mathrm{R}$. In contrast, the indirect pathway neurons co-express inhibitory $\mathrm{D}_{2} \mathrm{R}$ and the excitatory adenosine $\mathrm{A}_{2 \mathrm{~A}} \mathrm{R}$ (Lee et al., 2016; Nam et al., 2013). The NAc primarily is regulated by several typical neurotransmitters such as glutamate, dopamine and histamine from other brain regions (Blum et al., 2012; Gipson et al., 2014; Goto \& O'Donnell, 2001; Malenka et al., 2009; Robison \& Nestler, 2011). Glutamatergic inputs from the Amyg, mPFC and vHipp are considered the most robust sources of input to the NAc (Britt et al., 2012), while input from the PVT and VTA were also reported (Ren et al., 2018; Yu et al., 2019). It is well established that the NAc plays a pivotal role in mesolimbic dopamine regulation, in which the dopaminergic neurons in the VTA and medial SNc are usually taken as the major dopaminergic inputs (Brog et al., 1993; Joel \& Weiner, 2000; Lynd-Balta \& Haber, 1994; Swanson, 1982). Additionally, the TMN is the sole source of histamine in human and mouse brains, and, the NAc is one of the few regions that receive its histaminergic regulation (Haas \& Panula, 2003; Inagaki et al., 1988; Swanson, 1982; Wada et al., 1991). Projection output from the NAc is widespread. Tracing by 
immunohistochemistry and electron microscopy revealed that the $D_{1} R / A_{1} R$ direct pathway neurons mainly project to the midbrain and lateral hypothalamus (Luo et al., 2018). Similarly, the $D_{2} R / A_{2 A} R$ indirect pathway neurons mainly send termini to the BF, lateral hypothalamus and midbrain (Zhang et al., 2013).
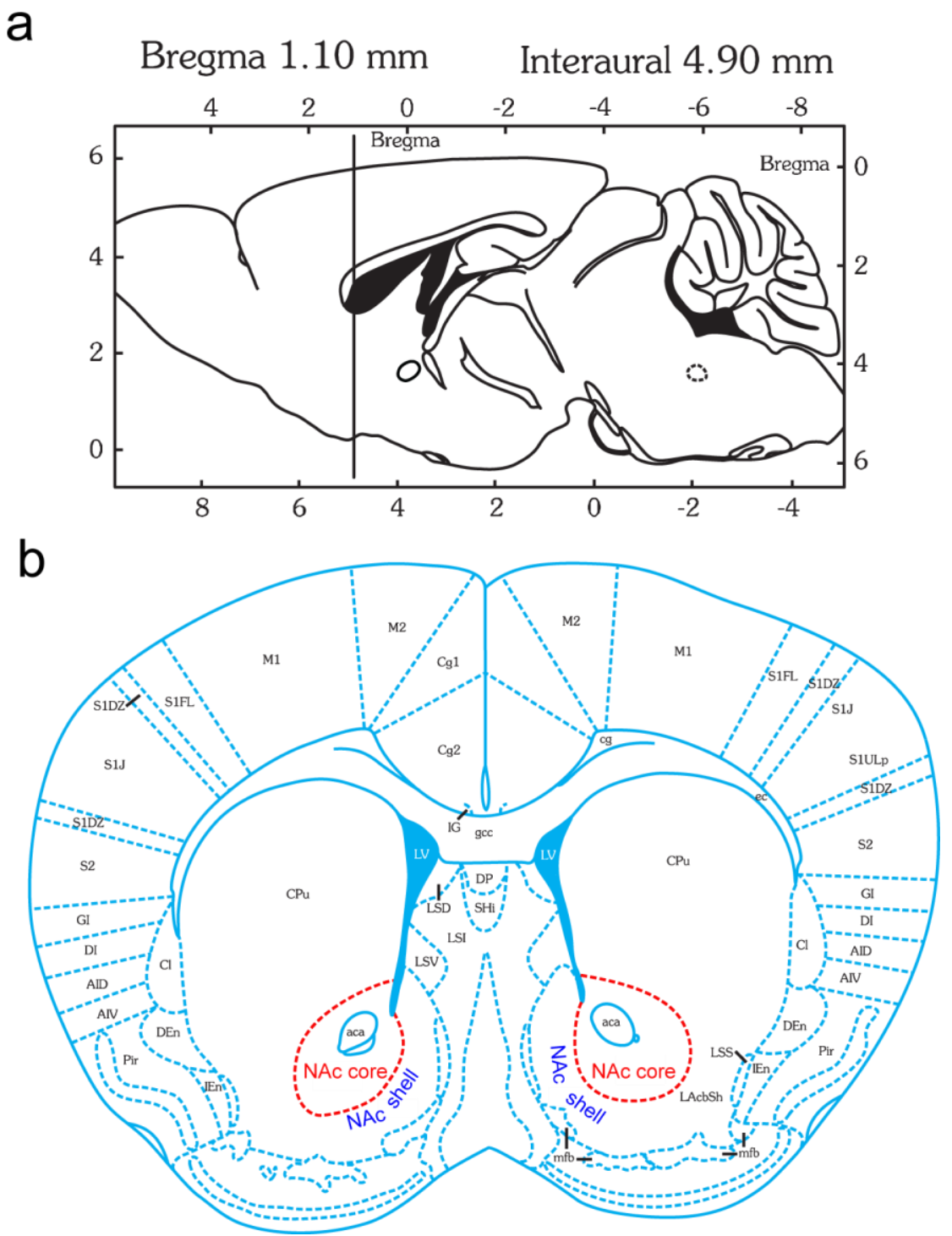

Figure 2. Scheme of anatomical representation of the NAc in the brain. a A typical sagittal representative section of the NAc in the brain. b The coronal section part of Fig 2a. Red dash lines and characters represent the NAc core and the dark blue characters indicates the NAc shell. (Modified from George Paxinos, \& Keith Franklin. (2001). The Mouse Brain in Stereotaxic Coordinates. 2nd edn. Academic Press.).

\subsubsection{The NAc plays an important role in sleep/wake regulation}


Previous studies revealed an important role of the NAc MSNs in regulating both sleep and arousal. Caffeine, as the most consumed psychoactive substances in the world every day, exerts its strong arousal effect via $\mathrm{A}_{2 \mathrm{~A}} \mathrm{R}$ in the NAc shell in mice (Huang et al., 2005; Lazarus et al., 2011). Bilateral nonspecific-neurotoxic lesion of the NAc core or shell by microinjected $1 \%$ ibotenic acid resulted in increased wakefulness in rats (Qiu et al., 2012). Besides, in-vivo electrophysiological recordings in the NAc discovered a decreased firing rate of numerous neurons during SWS in rats (Tellez et al., 2012). Further study revealed that opto- and chemogenetic activation of $\mathrm{D}_{1} \mathrm{R}$ direct pathway neurons can induce fast transitions from SWA to arousal and prolonged wakefulness, indicating that $D_{1} R / A_{1} R$ positive neurons in the NAc play an important role in arousal onset and maintenance (Luo et al., 2018). Moreover, Oishi and colleagues uncovered a prominent role of $\mathrm{A}_{2 \mathrm{~A}} \mathrm{R}$ expressing neurons in the NAc in sleep/wake regulation and proposed a novel brain circuit (NAc core - VP) for sleep control by motivated behavior (Oishi et al., 2017). Activation of the indirect pathway $D_{2} R / A_{2 A} R$ expressing neurons in the NAc core robustly induces sleep, however, inhibition of these neurons decreases sleep baseline without disturbing sleep homeostasis, indicating a necessity of these neurons in sleep. Besides, motivational stimuli inhibit the activity of the VP-projecting NAc $A_{2 A} R$ expressing neurons and suppress sleep (Oishi et al., 2017). This brain circuit may explain the tendency to fall asleep in the absence of motivating stimuli, i.e., when bored. However, how these sleep-promoting $\mathrm{D}_{2} \mathrm{R} / \mathrm{A}_{2 \mathrm{~A}} \mathrm{R}$ expressing neurons are activated in-vivo is still unknown. Adenosine is an obvious candidate molecule that activates NAc $\mathrm{A}_{2 \mathrm{~A}} \mathrm{R}$-expressing neurons because sufficient levels of adenosine are 
available under basal conditions and bind to excitatory $A_{2 A} R$. The source of the adenosine, however, remains obscure.

\subsection{Astrocyte, a promising source of extracellular adenosine}

Astrocytes, also known as astroglia, are a kind of glia cells distributed throughout the brain and spinal cord (the other kinds of glia cells are microglia and oligodendrocyte). This kind of star-shaped cell constructs the biggest cell population in the brain, outnumbering neurons five-fold (Sofroniew \& Vinters, 2010). Astrocytes are well known for many classical functions like structural support (forming blood vessels and the BBB), balancing extracellular concentration of ions and neurotransmitters, nutrition delivery, synaptic transmission modulation, and so on (Brooks, 2009; Sofroniew \& Vinters, 2010). A protein named as GFAP expressed by astrocytes plays an essential role in exerting their functions especially when they are activated and form into astrogliosis (Pekny et al., 1995; Pekny \& Pekna, 2004; Sofroniew, 2009). It is well known that GFAP is a typical and specific astroglial marker since, generally, neurons and other glia do not express this protein. However, only a fraction of astrocytes ( $20 \%$ to $40 \%$ ) express detectable GFAP mRNA in basal condition (Sofroniew, 2009; Sofroniew \& Vinters, 2010). This made GFAP a reliable marker in labelling reactivated astrocytes but notorious in labelling basal ones, compared to the other specific astroglial markers, for example, $\mathrm{S} 100 \beta$.

For a long time, astrocytes were taken for granted as inert participants in regulating behavioral functions since they are "silent", i.e., they cannot fire like neurons. But with 
developing knowledge and neurobiological techniques, a number of novel functions of astrocytes, especially involvement in sleep regulation, are starting to emerge. It is well established that adenosine (and ATP, which is rapidly degraded into adenosine) can be released in the brain from neurons and glia cells. Genetically engineered mice in which a dnSNARE domain is selectively expressed in astrocytes to non-specifically block the release of ATP exhibit decreased levels of extracellular adenosine (Chen \& Scheller, 2001; Pascual et al., 2005; Raingo et al., 2012). Although in these mice, the amount of wakefulness, SWS and REM sleep are indistinguishable from that in wild-type mice, they exhibit reduced SWA and recovery sleep after sleep deprivation (Halassa et al., 2009), suggesting that adenosine released from astrocytes is involved in an accumulation of sleep pressure. Direct proof is still lacking, however, and thus the exact sources of adenosine remain unknown. Work by Greene and colleagues provides evidence for adenosine-mediated regulation of the homeostatic sleep need via activation of neuronal $A_{1} R$ controlled by glial AdK (Bjorness et al., 2009, 2016). As a matter of fact, mice deficient in glial AdK exhibit increased SWA rebound and consolidation, and an increased time constant of SWA during an average sleep episode. These findings implicate astrocytes as a promising source of adenosine in sleep regulation; however, the role of NAc astrocytes in sleep regulation is not known.

\subsection{Diphtheria toxin and its novel applications in research}

Diphtheria toxin is an exotoxin secreted by corynebacterium diphtheria, which is famous for causing the severe disease "diphtheria" after infection. It consists of two 
fragments: fragment A and B. When the diphtheria toxin contacts a cell expressing its receptor, fragment $\mathrm{B}$ binds to it followed by penetration through the cellar membrane (Bell \& Eisenberg, 1996; Mitamura et al., 1995). Fragment A is cleaved and released after reaching the cytosol of the victim cell and soon kills the cell by inhibiting a subunit ADP-ribosylates host EF-2 which is required for protein synthesis (Honjo et al., 1968; Kimata \& Kohno, 1994; Kohno et al., 1986; Kohno \& Uchida, 1987; Robinson et al., 1974; Van Ness et al., 1980). Diphtheria toxin fragment A is extremely toxic. A cell can be killed by even just one molecule of DTA in the cytosol (Yamaizumi et al., 1978). Humans and monkeys are highly susceptible to the diphtheria toxin, however, mice and rats are resistant. A comparative study showed that the native DTR of rodents lacks a transport process, thus explaining the lower efficiency of the toxin compared to humans or monkeys (Chang \& Neville, 1978).

The diphtheria toxin fragment A is widely used in cell ablation studies. Cytotoxic DTA genes are usually specifically expressed in the ablation target cells directly by classic AAV vector or transgenic mice, especially Cre-recombinase dependent mice created by the CRISPR-Cas9 genome editing method (Brockschnieder et al., 2004; Kohlschutter et al., 2010; Palmiter et al., 1987). However, there is a conspicuous deficiency of these tools in which the ablation of cells immediately starts after DTA expression. Thus it is impossible to measure baseline parameters. For example, in neurobiological experiments, mice usually need several days to recover from the injuries caused by virus injection. However, cell ablation starts from the moment of infection, which makes it impossible to assess accurate baseline parameters during recovery. Therefore, 
to solve this issue, specific expression of DTR (usually from monkey) in mice were established (Iwasaki et al., 2018; Saito et al., 2001).

\section{The aim of this study}

In this study, we aimed to ablate GFAP positive cells in the NAc to investigate if there is any change in sleep/wake cycle, using virus-mediated expression of DTR and intraperitoneal administration of DT. Meanwhile immunohistochemical and neurochemical investigations related to the behavioral study were also performed.

\section{Materials and methods}

\subsection{Animals}

A mouse strain expressing EYFP in mouse GFAP-positive cells (lox-stop-loxEYFP/mGFAP-Cre) was established by crossing R26-stop-EYFP mice (Jackson Laboratory, strain number 007903) (Srinivas et al., 2001) with mGFAP-Cre mice (Garcia et al., 2004). In addition, a global $A_{2 A} R$ knockout mouse line was used (Chen et al., 1999). All mice (weighing 20-35 g, 8-24 weeks old) used in the present study were housed at a constant temperature of $23 \pm 1{ }^{\circ} \mathrm{C}$ with a relative humidity of $60 \pm 2 \%$ in an automatically controlled 12-h light/dark cycle (lights on at 7:00, off at 19:00), and provided with water and food ad libitum. All experiments were performed in accordance with the Animal Care Committee of the University of Tsukuba and the National Institutes of Health Guide for the Care and Use of Laboratory Animals, and every effort was made to minimize the number of animals used, as well as any pain and 
discomfort.

\subsection{Plasmids and AAV generation}

To generate the pAAV-GFAP-DTR-P2A-mCherry plasmid, the hM4D(Gi) fragment in pAAV-GFAP-hM4D(Gi)-mCherry, kindly provided by Dr. Bryan Roth (University of North Carolina; Addgene plasmid \#50479), was replaced with a PCR-amplified fragment containing the DTR-P2A coding sequence using restriction cloning.

The AAV serotypes of shH10 for recombinant AAV-GFAP-DTR-mCherry and AAVGFAP-mCherry were generated as described previously (Zolotukhin et al., 1999). In brief, the AAVs were generated by tripartite transfection into 293A cells. After 3 days, the 293A cells were resuspended in artificial cerebrospinal fluid, freeze-thawed four times, and treated with Benzonase ${ }^{\circledR}$ nuclease (Millipore, Burlington, MA) to degrade all forms of DNA and RNA. Subsequently, the cell debris was removed by centrifugation and the virus titer in the supernatant was determined using an AAVpro Titration Kit for Real Time PCR (Takara Bio, Kusatsu, Japan).

\subsection{Stereotaxic AAV injection, EEG/EMG recordings and vigilance state assessment}

Surgeries for brain microinjections were conducted under pentobarbital anesthesia (60 mg/kg, i.p.). Using aseptic techniques, the mice were stereotaxically and bilaterally injected into the NAc with recombinant AAV-GFAP-DTR-mCherry (264 nl/side, $1 \times 10^{11}$ particles $\mathrm{ml}^{-1}$ ) or AAV-GFAP-mCherry $\left(264 \mathrm{nl} /\right.$ side, $9 \times 10^{10}$ particles $\left.\mathrm{ml}^{-1}\right)$ 
with a glass micropipette and an air pressure injector system (Chamberlin et al., 1998). The following coordinates were used according to the mouse brain atlas of Paxinos and Franklin (2001): AP + $1.5 \mathrm{~mm} ; \mathrm{ML} \pm 1.2 \mathrm{~mm}$; DV $-4.1 \mathrm{~mm}$.

Mice were chronically implanted with EEG and EMG electrodes for polysomnography, as previously described (Oishi et al., 2016). Briefly, the implant contained two stainlesssteel screws (1 mm diameter) serving as EEG electrodes, one of which was placed epidurally over the right frontal cortex (1.0 $\mathrm{mm}$ anterior and $1.5 \mathrm{~mm}$ lateral to bregma) and the other over the right parietal cortex $(1.0 \mathrm{~mm}$ anterior and $1.5 \mathrm{~mm}$ lateral to lambda). Two insulated Teflon-coated, silver wires $(0.2 \mathrm{~mm}$ in diameter $)$, which were placed bilaterally into the trapezius muscles, served as EMG electrodes. Both EEG and EMG electrodes were connected to a microconnector, and the whole assembly was then fixed to the skull with self-curing dental acrylic resin.

After recovering for at least 3 weeks, the mice were connected to an EEG/EMG recording cable in a soundproof recording chamber and habituated for at least 3 days before any polysomnographic recording (Figure 3a, b, c). The EEG/EMG signals were amplified, filtered (EEG, 0.5-30 Hz; EMG, 20-200 Hz), digitized at a sampling rate of $128 \mathrm{~Hz}$, and recorded using SLEEPSIGN software ver. 3 (Kissei Comtec, Matsumoto, Japan) (Kohtoh et al., 2008). 

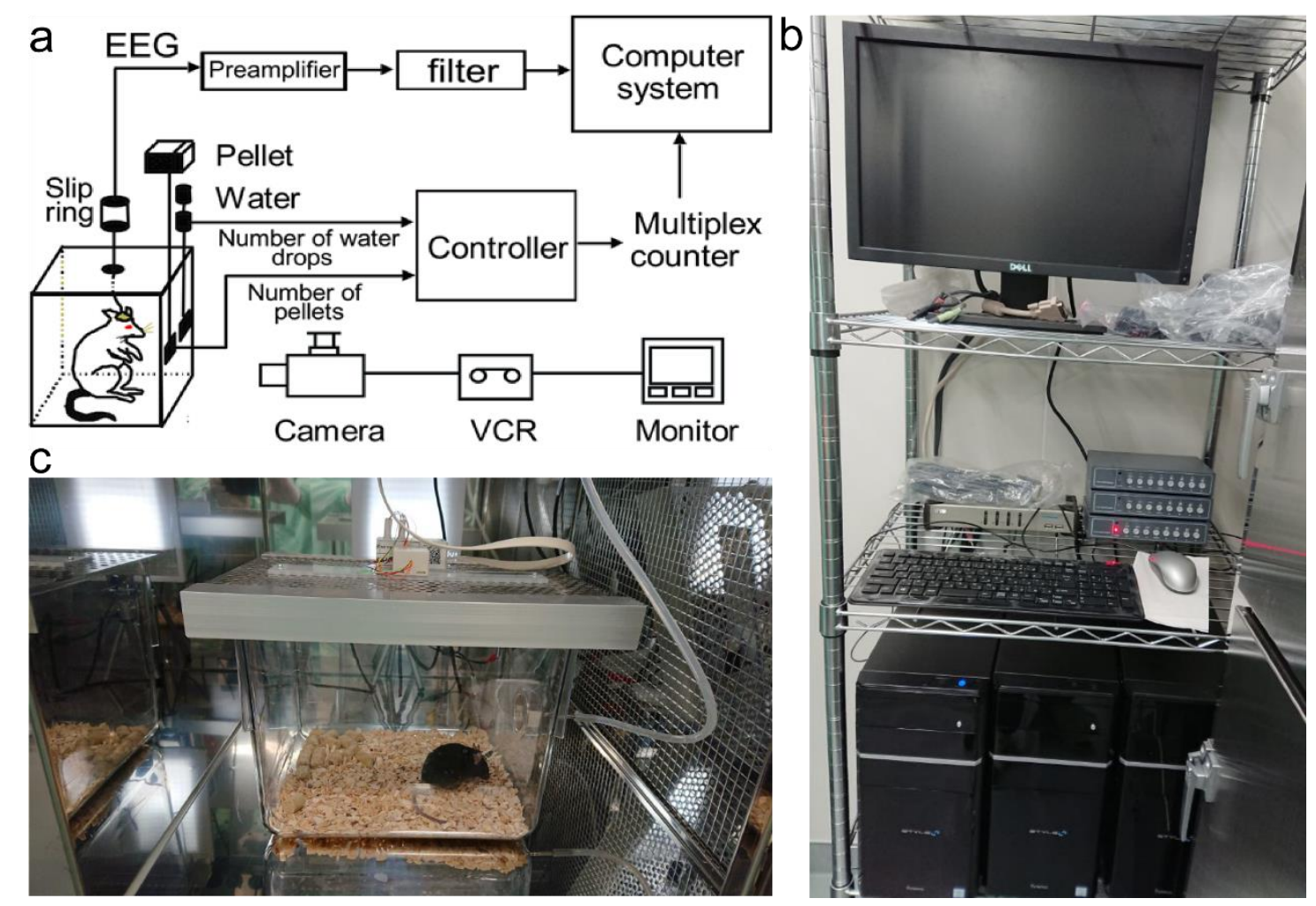

Figure 3. Schematic diagram of the polysomnographic recording system in Lazarus lab in IIIS. a Schematic representation of the polysomnographic recording system. b Computers and video monitors used for sleep recording. c A mouse undergoing recording in the recording chamber.

EEG/EMG data visualized by the analysis software were calculated in 10-s epochs and three stages were recognized based on their spectrum and wave properties (Oishi et al., 2016): SWS, rapid eye movement (REM) sleep, and wakefulness (Fig 4). SWS is recognized by low-frequency, synchronized high-amplitude and spindle-like EEG, silenced EMG and a high percentage of delta power (0.5-4.0 Hz) (Fig 4). In contrast, wakefulness is distinguished by high-frequency but low amplitude and desynchronized EEG and active EMG (Fig 4). REM sleep EEG looks like wakefulness but with almost silenced EMG and a remarkably high theta power (Fig 4). Percent change of slow-wave activity was also calculated based on the SWS delta power $(0.5-4 \mathrm{~Hz})$ during $24 \mathrm{~h}$ and normalized to the baseline condition. 


\section{SWS}

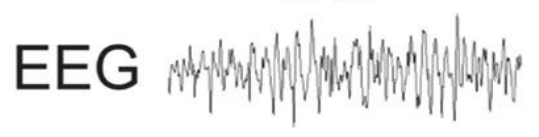

EMG

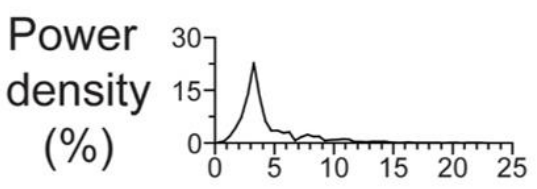

REM sleep
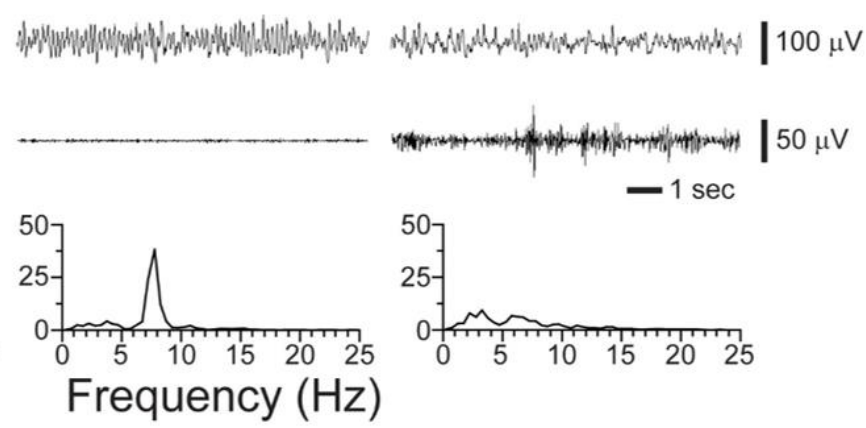

Wakefulness
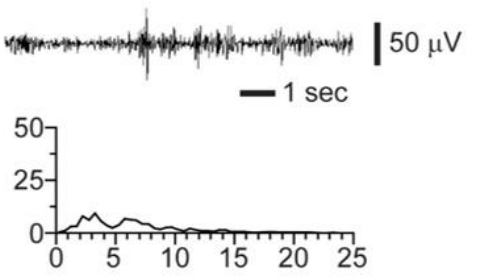

Figure 4. The characterizations of vigilance stages : SWS, REM sleep and wakefulness.

\subsection{Microdialysis in freely behaving mice and measurement of adenosine by HPLC}

Under pentobarbital anesthesia $(60 \mathrm{mg} / \mathrm{kg}$, i.p. $)$, mice were bilaterally implanted with guide cannulas (inner diameter $0.40 \mathrm{~mm}$, outer diameter $0.50 \mathrm{~mm}$; Eicom, Kyoto, Japan) into the brain using the following coordinates according to the mouse brain atlas of Paxinos and Franklin (2001): AP +1.4 mm; ML $\pm 1.2 \mathrm{~mm}$; DV -2.9 mm. Two stainlesssteel screws (1 mm diameter) were also implanted to stabilize the guide cannulas, and then dummy cannulas (diameter $0.37 \mathrm{~mm}$, Eicom) were inserted to prevent the guide cannula from clogging. After recovering for at least 3 weeks, the mice were transferred to the recording chambers for habituation. On the sampling day, each mouse was quickly anesthetized using isoflurane and the dummy cannula was removed followed by insertion of the microdialysis probe $(1 \mathrm{~mm}$ membrane length, $8.4 \%$ adenosine recovery rate; Eicom) into the guide cannula. The probe was infused continuously using an infusion pump with Ringer's solution (147 mM NaCl, $4 \mathrm{mM} \mathrm{KCl}$, and $2.4 \mathrm{mM} \mathrm{CaCl}_{2}$ ) at a flow rate of $0.5 \mu \mathrm{l} / \mathrm{min}$ (Figure 5a). Two hours after inserting the probe, dialysates 
were continuously collected from the probe for $3 \mathrm{~h}$ (Figure 5a). The dialysates were kept at $-20^{\circ} \mathrm{C}$ until adenosine was measured by HPLC (Figure 5b). A TSKgel ${ }^{\circledR}$ ODS100V HPLC column (Tosoh Bioscience, Tokyo, Japan) together with a mobile phase comprising $100 \mathrm{mM} \mathrm{NaH} \mathrm{PO}_{4}$ and acetonitrile in a ratio of 96:4 at a flow rate of 1 $\mathrm{ml} / \mathrm{min}$ was used for HPLC separation, and $80 \mu \mathrm{l}$ of each dialysate was injected into a HPLC-LabSolutions LC system (Shimadzu, Kyoto, Japan) equipped with a UV (260 nm) detection system. External adenosine standards were used to determine the retention time and to calculate the adenosine concentrations in the dialysates by the HPLC software (Figure 5c).

a

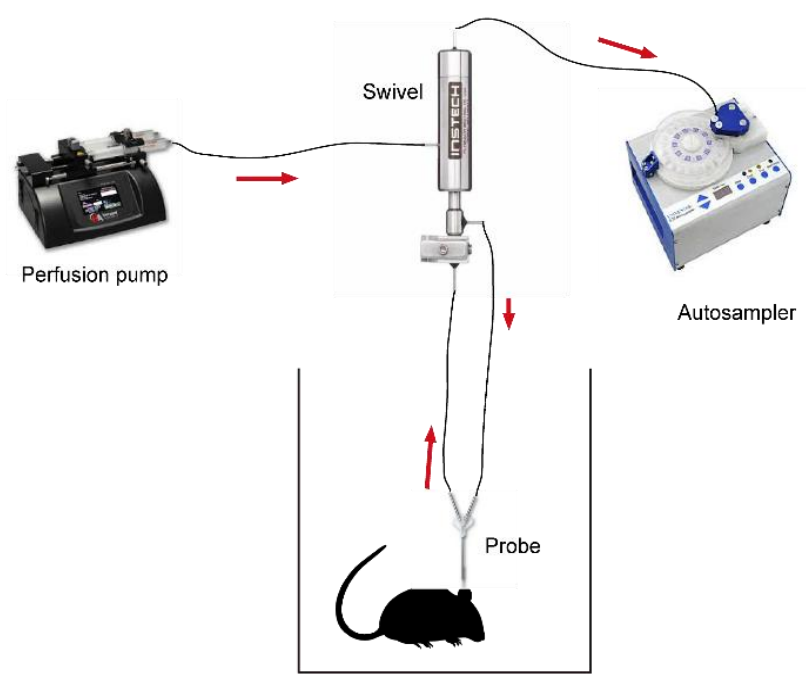

Schematic representation for microdialysis collection

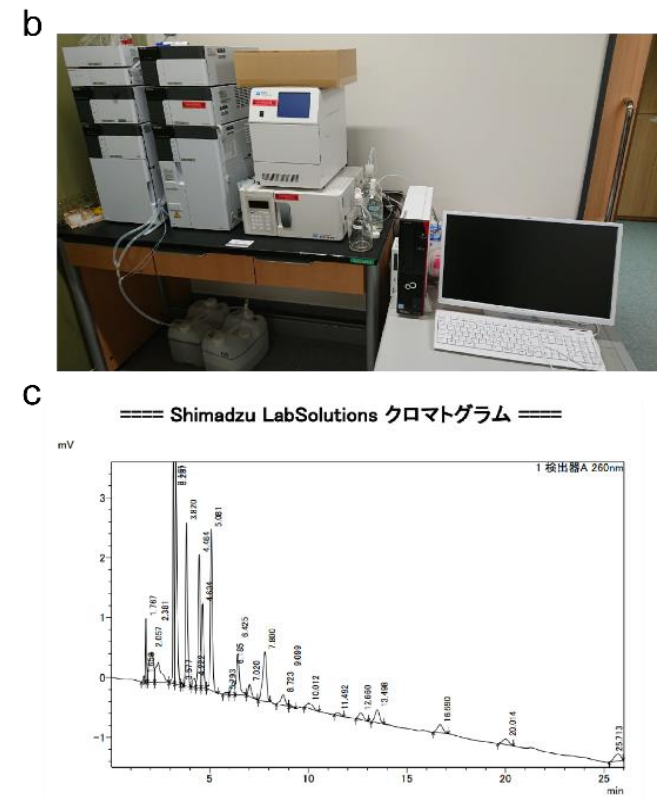

Figure 5. Schematic representations of the adenosine assay system. a Schematic representation of microdialysis in freely moving mice. b Shimadu-LabSolution HPLC system used in this study in the IIIS. c A typical chromatograph of a dialysate sample analyzed by the HPLC system.

\subsection{Histology}

Under deep chloral hydrate $(500 \mathrm{mg} / \mathrm{kg}$, i.p. $)$ anesthesia, the mice were perfused via the heart with saline followed by a $10 \%$ formalin solution. The brains were removed and 
immersed in the same fixative overnight at $4{ }^{\circ} \mathrm{C}$ and then transferred into a $20 \%$ sucrose solution.

For immunohistochemistry, the brains were then frozen on dry ice and sectioned at $40 \mu \mathrm{m}$ on a freezing microtome (Thermo Fisher Scientific, Waltham, MA). Immunohistochemistry was performed on free-floating sections as described previously (Lazarus et al., 2011). In brief, the sections were rinsed in PBS, incubated in $0.3 \%$ hydrogen peroxide in PBS for $30 \mathrm{~min}$ at room temperature, and then sequentially incubated at room temperature in 3\% normal donkey serum and $0.25 \%$ Triton X-100 in PBS (PBT) for $1 \mathrm{~h}$ and then overnight in primary antibody diluted in PBT with $0.02 \%$ sodium azide. After overnight incubation with rabbit anti-DsRed antibody (1:5000; Cat\# 632496, Takara Bio), the sections were rinsed and incubated for $2 \mathrm{~h}$ in biotinylated antibody (Jackson ImmunoResearch Lab, West Grove, PA) at a dilution of 1:1000. All tissue sections were then treated with avidin-biotin complex (1:1000; Vectastain ABC Elite kit, Vector Labs, Burlingame, CA) for $1 \mathrm{~h}$, and immunoreactive cells were visualized by reaction with $3,3^{\prime}$-diaminobenzidine and $0.01 \%$ hydrogen peroxide. Tissue sections mounted on glass slides were scanned with a Hamamatsu NanoZoomerXR Digital slide scanner (Hamamatsu Photonics, Hamamatsu, Japan), and digital photomicrographs were analyzed using Hamamatsu NDPView software v2.4.26.

For fluorescent double-labeling, the sections were rinsed in PBT and incubated in PBT containing 10\% BlockAce (DS PharmaBiomedical, Osaka, Japan) for $30 \mathrm{~min}$ at room temperature. The sections were then incubated with the rabbit anti-GFAP antibody (1:200, Cat\# HPA056030, Sigma-Aldrich, St. Louis, MO), goat anti-mCherry antibody 
(1:1000, Cat\# AB0040-200, SICGEN, Cantanhede, Portugal), mouse anti-NeuN antibody (1:100, Cat\# MAB377, Millipore), rabbit anti-S100ß (1:100, Cat\# HPA015768, Sigma-Aldrich, St. Louis, MO) or rabbit anti-TMEM119 antibody (1:200, Cat\# ab209064, Abcam, Cambridge, UK) containing 5\% BlockAce at room temperature in the combinations described in the Results section. After overnight incubation, the sections were rinsed in PBT and incubated with donkey anti-goat Alexa Fluor ${ }^{\circledR} 594$ nm (1:1000, Thermo Fisher Scientific), donkey anti-mouse Alexa Fluor ${ }^{\circledR}$ 647 nm (1:500, Thermo Fisher Scientific), or donkey anti-rabbit Alexa Fluor® 647 nm (1:500, Thermo Fisher Scientific) containing 5\% BlockAce for at least $2 \mathrm{~h}$. The sections were then mounted on glass slides and sealed with mounting medium containing DAPI dye (Vector Labs, Cat\# H-1200) and cover glass. Fluorescence signals were visualized using an LSM 700 confocal microscope (Zeiss, Oberkochen, Germany).

For quantitative histologic analysis, pictures of tissues containing the NAc at the same bregma level were obtained using a confocal microscope in the $\mathrm{Z}$ stack mode. In Fig. 6b, a $0.35 \mathrm{~mm} \times 0.35 \mathrm{~mm}$ area in the NAc of each tissue was analyzed. The percentage of NeuN/mCherry and S100ß/mCherry-positive cells among mCherry/DAPI-positive cells was calculated. In Fig. 8g, the number of GFAP/DAPI-positive cells was counted in and normalized to the AAV area. The AAV area (i.e., the area showing mCherry expression) was measured using ImageJ software.

\subsection{Statistical analysis}

Data are presented as mean \pm standard error of the mean (SEM) and were analyzed using SPSS statistics 25 (IBM, Armonk, NY). One-way ANOVA followed by the 
Fisher's Protected Least Significant Difference test or two-way ANOVA followed by the PLSD test was performed for all the statistical analysis. In all cases, a p-value less than 0.05 was considered significant.

\section{Results}

\subsection{SWS increased after cytotoxic ablation of NAc GFAP-positive cells.}

To examine the role of NAc astrocytes in sleep-wake regulation, we ablated GFAPpositive cells in the NAc core of mice by stereotaxic microinjection of AAV carrying DTR under a GFAP promoter (AAV-GFAP-DTR, Fig. 6a) and i.p. injection of DT (Wako, Japan) 3 weeks after microinjection. AAV-GFAP-DTR was injected in lox-stoplox-EYFP/mGFAP-Cre mice, denoted as $\mathrm{A}_{2 \mathrm{~A}} \mathrm{R}^{\mathrm{WT}}$ mice, or $\mathrm{A}_{2 \mathrm{~A}} \mathrm{R}$ knockout mice $\left(\mathrm{A}_{2 \mathrm{~A}} \mathrm{R}^{\mathrm{KO}}\right.$ mice $)$.

First, we evaluated the specificity of DTR expression in AAV-GFAP-DTR-injected $\mathrm{A}_{2 \mathrm{~A}} \mathrm{R}^{\mathrm{WT}}$ mice by immunohistochemical investigation of the expression of the neuronal marker NeuN, the astrocytic marker $\mathrm{S} 100 \beta$ and the AAV-reporter protein mCherry (Fig. 6b). We detected $21.4 \% \pm 3.5 \%$ of NeuN/mCherry-positive cells and $73.0 \% \pm 5.8 \%$ of S100ß/mCherry-positive cells among all mCherry-positive cells across six NAccontaining brain sections from three mice in each group, suggesting that most infected cells were astrocytes but a minority were neurons. 
a
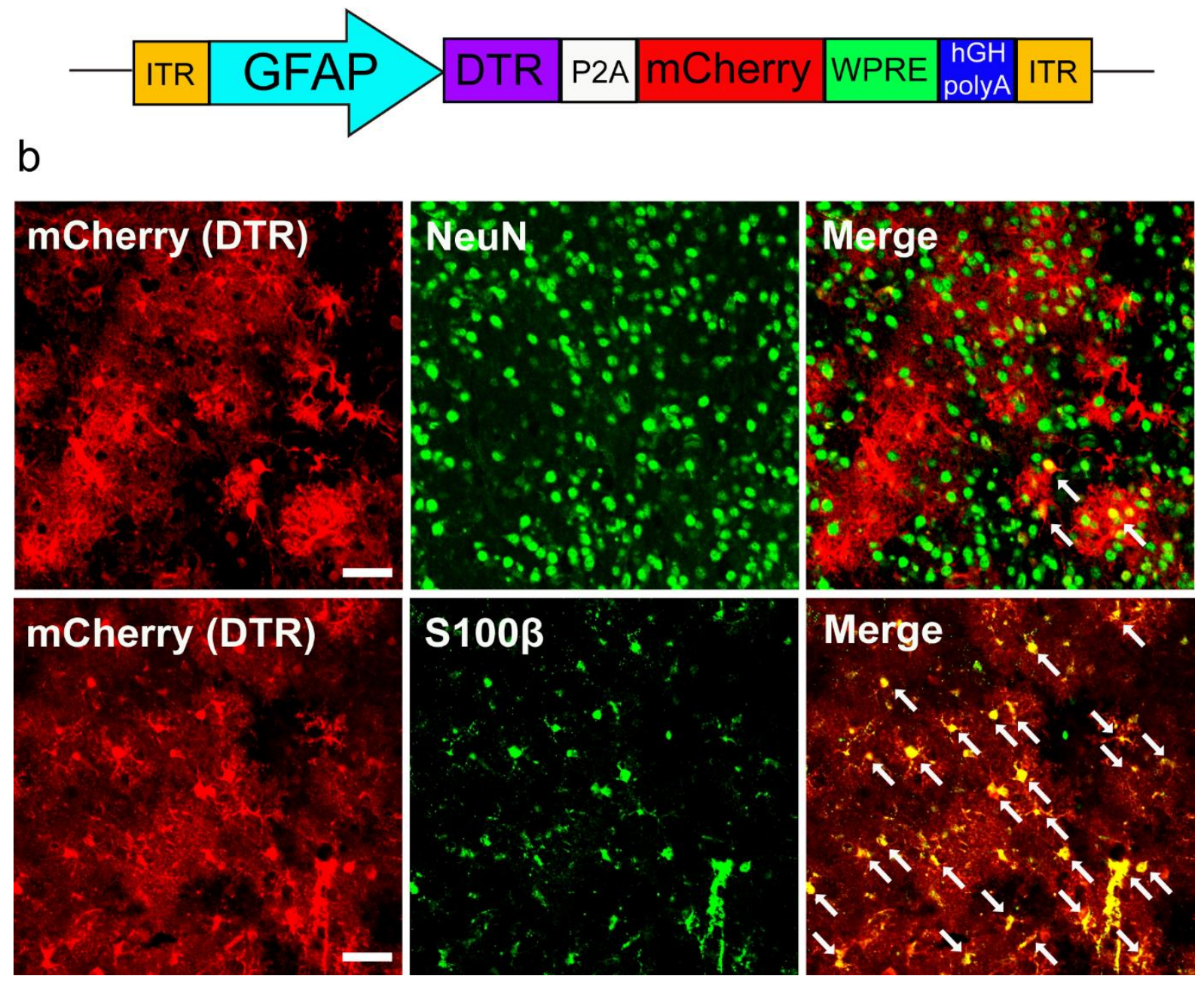

Figure 6. Adeno-associated virus-mediated expression of diphtheria toxin receptors. a Construct for multi-gene expression of DTR and mCherry via 2A self-cleaving peptide driven by the GFAP-promoter. b DTR is expressed in astrocytes and a small number of neurons after AAV infection as revealed by immunohistochemical staining with antibodies against the neuronal marker NeuN, astrocytic marker S100 $\beta$ and AAV reporter protein mCherry. White arrows indicate NeuN/mCherry-positive (top right panel) or S100 $\beta / \mathrm{mCherry-positive} \mathrm{(bottom} \mathrm{right} \mathrm{panel)} \mathrm{cells.} \mathrm{Scale} \mathrm{bar:} 40 \mu \mathrm{m}$.

Next, we stereotaxically microinjected AAV-GFAP-DTR bilaterally into the NAc core of $\mathrm{A}_{2 \mathrm{~A}} \mathrm{R}^{\mathrm{WT}}$ mice, denoted as $\mathrm{A}_{2 \mathrm{~A}} \mathrm{R}^{\mathrm{WT}}$ NAc GFAP-DTR mice, and as controls, we injected AAV-GFAP-mCherry into the NAc core of $A_{2 A} R^{W T}$ mice $\left(A_{2 A} R^{W T} N A c\right.$ GFAPmCherry mice; Fig. 7a, b). Three weeks after the AAV injections, EEG and EMG recordings of the mice were analyzed to assess the baseline sleep/wake behavior of the 
animals. Initially, only $\mathrm{A}_{2 \mathrm{~A}} \mathrm{R}^{\mathrm{WT}} \mathrm{NAc}$ GFAP-DTR mice were treated with DT (50 $\mu \mathrm{g} / \mathrm{kg}$, i.p.), and EEG and EMG recordings were obtained on days 9 to 14 following the treatment. We analyzed SWS amounts in $\mathrm{A}_{2 \mathrm{~A}} \mathrm{R}^{\mathrm{WT}}$ NAc GFAP-DTR mice during dark and light periods compared with the baseline. We found that SWS was significantly increased in the dark and light periods of day 9 and then gradually returned to the baseline level until day 14 (Fig. 7c). Therefore, we next obtained EEG and EMG recordings of $\mathrm{A}_{2 \mathrm{~A}} \mathrm{R}^{\mathrm{WT}} \mathrm{NAc}$ GFAP-DTR and NAc GFAP-mCherry mice for 9 days after DT treatment. SWS increased in the $\mathrm{A}_{2 \mathrm{~A}} \mathrm{R}^{\mathrm{WT}} \mathrm{NAc}$ GFAP-DTR mice during the dark period from day 5 after DT treatment before reaching a maximum on day 7 after DT treatment, compared with DT-treated control mice (day 5: $F_{(1,9)}=7.808, p=0.011$; day 6: $F_{(1,9)}=6.470, p=0.024 ;$ day $7: F_{(1,9)}=21.858, p=0.0001 ;$ day $8: F_{(1,9)}=6.907, p=0.026$ day 9: $F_{(1,9)}=8.050, p=0.023$; Fig. 7d). SWS also increased significantly in the $\mathrm{A}_{2 \mathrm{~A}} \mathrm{R}^{\mathrm{WT}}$ NAc GFAP-DTR mice during the light period between days 1 and 8, compared to the DT-treated control mice (day 1: $F_{(1,9)}=3.948, p=0.015$; day 2: $F_{(1,9)}=7.591, p=0.002$; day 3: $F_{(1,9)}=3.205, p=0.024$; day $4: F_{(1,9)}=2.971, p=0.031$; day $5: F_{(1,9)}=4.316$, $p=0.012$; day 6: $F_{(1,9)}=4.379, p=0.021$; day $7: F_{(1,9)}=8.384, p=0.011$; day $8: F_{(1,}$ 9) $=6.679, p=0.013$; Fig. 7d). We also stereotaxically microinjected AAV-GFAP-DTR bilaterally into the NAc core of $\mathrm{A}_{2 \mathrm{~A}} \mathrm{R}^{\mathrm{KO}}$ mice, denoted as $\mathrm{A}_{2 \mathrm{~A}} \mathrm{R}^{\mathrm{KO}}$ NAc GFAP-DTR mice, and as controls, we injected AAV-GFAP-mCherry into the NAc core of $\mathrm{A}_{2 \mathrm{~A}} \mathrm{R}^{\mathrm{KO}}$ mice $\left(\mathrm{A}_{2 \mathrm{~A}} \mathrm{R}^{\mathrm{KO}}\right.$ NAc GFAP-mCherry mice; Fig. 7a). SWS was not increased in DTtreated $A_{2 A} R^{K O}$ NAc GFAP-DTR mice, however, compared with $A_{2 A} R^{K O}$ NAc GFAPmCherry mice in either the dark or light periods (Fig. 7e). This observation suggests 
that the SWS increase after DT treatment is mediated by adenosine via $\mathrm{A}_{2 \mathrm{~A}} \mathrm{R}$.

On day 7 , when the mice had the strongest SWS increase, $\mathrm{A}_{2 \mathrm{~A}} \mathrm{R}^{\mathrm{WT}}$ NAc GFAP-DTR mice exhibited increased SWS and REM sleep, especially during the dark period, compared with DT-treated control mice (Fig. 7f, g). Concomitantly, $\mathrm{A}_{2 \mathrm{~A}} \mathrm{R}^{\mathrm{WT}}$ NAc GFAP-DTR mice had a lower amount of wakefulness. By contrast, we did not observe notable changes in the hourly SWS and REM sleep amounts of $\mathrm{A}_{2 \mathrm{~A}} \mathrm{R}^{\mathrm{KO}}$ NAc GFAPDTR mice on day 7 after DT treatment, compared with $\mathrm{A}_{2 \mathrm{~A}} \mathrm{R}^{\mathrm{KO}}$ NAc GFAP-mCherry mice (Fig. 7h, i). The increased amount of SWS in $\mathrm{A}_{2 \mathrm{~A}} \mathrm{R}^{\mathrm{WT}}$ NAc GFAP-DTR mice during the dark period of day 7 after DT treatment was due to an increased number of SWS episodes, while the mean duration of SWS episodes was not changed (Fig. 7j, k). A change in SWA is considered a hallmark of sleep homeostasis disturbance (Dispersyn et al., 2017; Wang et al., 2018). To investigate whether sleep homeostasis was affected by cytotoxic ablation of NAc GFAP-positive cells, we calculated changes in SWA on day 7 normalized to the baseline; however, there was no significant difference in the normalized SWA in all the mouse groups (Fig. 7l, $\mathbf{m})$. 
a

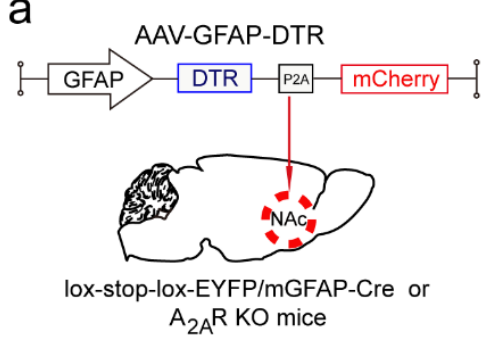

b

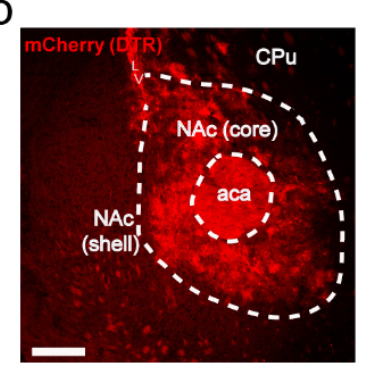

C

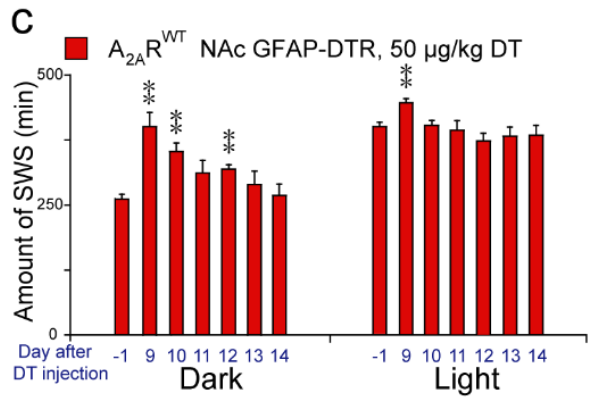

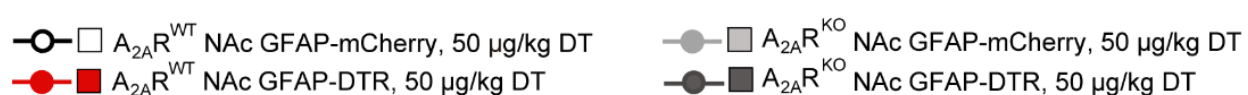

d
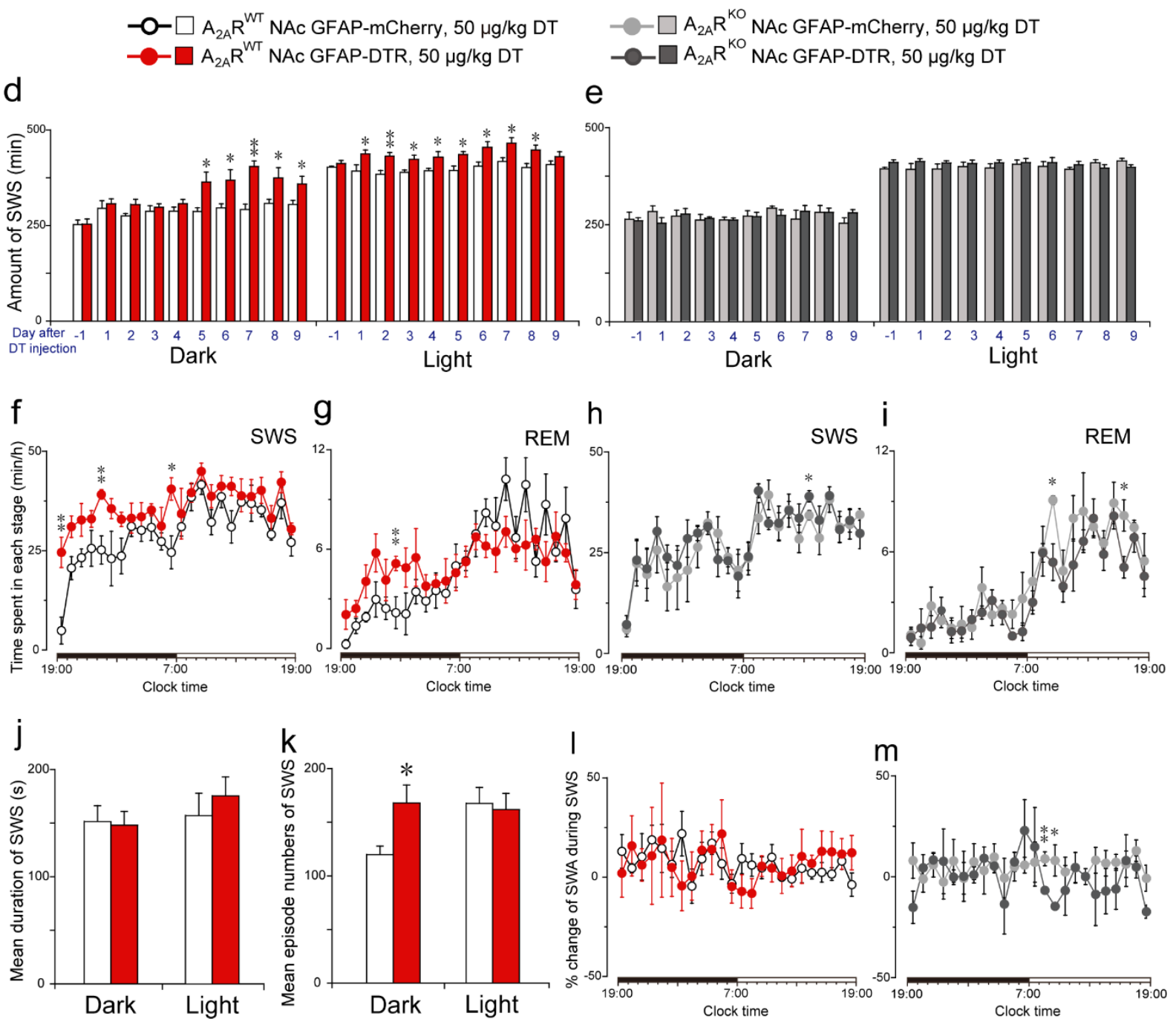

Figure 7. SWS is increased after cytotoxic ablation of GFAP-positive cells in the NAc core in $\mathrm{A}_{2 \mathrm{~A}} \mathrm{R}^{\mathrm{WT}}$ but not in $\mathrm{A}_{2 \mathrm{~A}} \mathrm{R}^{\mathrm{KO}}$ NAc GFAP-DTR mice. a AAV-GFAP-DTR was bilaterally microinjected into lox-stop-lox-EYFP/mGFAP-Cre $\left(\mathrm{A}_{2 \mathrm{~A}} \mathrm{R}^{\mathrm{WT}}\right)$ or $\mathrm{A}_{2 \mathrm{~A}} \mathrm{R}^{\mathrm{KO}}$ mice. b Typical AAV infection in the NAc core as indicated by mCherry expression. Scale bar: $200 \mu \mathrm{m}$. c SWS during the dark and light periods 1 day before and at 9 to 14 days after DT treatment in $\mathrm{A}_{2 \mathrm{~A}} \mathrm{R}^{\mathrm{WT}} \mathrm{NAc}$ GFAP-DTR mice $(n=4)$. **p $<0.01$ vs baseline day (i.e., day before DT treatment), assessed by one-way ANOVA. d SWS during the dark and light periods 1 day before and for 9 days after DT treatment in $\mathrm{A}_{2 \mathrm{~A}} \mathrm{R}^{\mathrm{WT}} \mathrm{NAc}$ GFAP-mCherry $(n=5)$ and NAc GFAP-DTR $(n=6)$ mice. $* p<0.05$, $* * p<0.01$ vs $\mathrm{A}_{2 \mathrm{~A}} \mathrm{R}^{\mathrm{WT}}$ NAc GFAP-mCherry mice; assessed by one-way ANOVA. e SWS during the dark and light periods 1 day before and for 9 days after DT treatment in $\mathrm{A}_{2 \mathrm{~A}} \mathrm{R}^{\mathrm{KO}} \mathrm{NAc}$ 
GFAP-mCherry $(n=4)$ and NAc GFAP-DTR $(n=6)$ mice. f-i SWS (f, h), and REMsleep $(\mathbf{g}, \mathbf{i})$ time-courses of all the mouse groups on day 7 after DT treatment. $* p<0.05$, $* * p<0.01$ vs $\mathrm{A}_{2 \mathrm{~A}} \mathrm{R}^{\mathrm{WT}}$ NAc GFAP-mCherry $(\mathbf{f}, \mathbf{g})$ or $\mathrm{A}_{2 \mathrm{~A}} \mathrm{R}^{\mathrm{KO}}$ NAc GFAP-mCherry (h, i) mice; assessed by two-way ANOVA followed by the PLSD test. $\mathbf{j}$, $\mathbf{k}$ Mean duration (j) and number (k) of SWS episodes during the dark and light periods on day 7 after DT treatment in $\mathrm{A}_{2 \mathrm{~A}} \mathrm{R}^{\mathrm{WT}}$ NAc GFAP-mCherry $(n=5)$ and $\mathrm{A}_{2 \mathrm{~A}} \mathrm{R}^{\mathrm{WT}}$ NAc GFAP-DTR $(n=6)$ mice. $*_{p}<0.05$ vs $\mathrm{A}_{2 \mathrm{~A}} \mathrm{R}^{\mathrm{WT}}$ NAc GFAP-mCherry mice, assessed by one-way ANOVA. l, $\mathbf{m}$ SWS-SWA time-courses of all the mouse groups on day 7 after DT treatment. ${ }^{*} p<0.05,{ }^{* *} p<0.01$ vs $\mathrm{A}_{2 \mathrm{~A}} \mathrm{R}^{\mathrm{KO}}$ NAc GFAP-mCherry mice; assessed by twoway ANOVA followed by the PLSD test.

\subsection{Cytotoxic ablation of NAc GFAP-positive cells led to increased activation of astrocytes and microglia}

We then evaluated the effects of cytotoxic ablation of GFAP-positive cells in the NAc after DT treatment by immunohistochemical investigation of the expression of the astrocyte-reporter protein EYFP and the AAV-reporter protein mCherry (Fig. 8a-c). No EYFP- and mCherry-positive cells were observed in $\mathrm{A}_{2 \mathrm{~A}} \mathrm{R}^{\mathrm{WT}}$ NAc GFAP-DTR mice after DT treatment (Fig. 8a), whereas many double-positive cells were observed in $\mathrm{A}_{2 \mathrm{~A}} \mathrm{R}^{\mathrm{WT}}$ NAc GFAP-DTR mice treated with saline or $\mathrm{A}_{2 \mathrm{~A}} \mathrm{R}^{\mathrm{WT}}$ NAc GFAP-mCherry mice treated with DT (Fig. 8b, c). These findings suggest that cells infected with AAVGFAP-DTR were completely ablated by the administration of DT.

Next, we examined the residual NAc astrocytes on day 7 after DT administration by immunohistochemical investigation of the expression of the endogenous astrocyte marker GFAP and the AAV-reporter protein mCherry (Fig. 8d-f). Surprisingly, GFAP expression was remarkably increased in $\mathrm{A}_{2 \mathrm{~A}} \mathrm{R}^{\mathrm{WT}}$ NAc GFAP-DTR mice treated with DT compared with $A_{2 A} R^{W T}$ NAc GFAP-DTR mice treated with saline or $A_{2 A} R^{\text {WT }}$ NAc GFAP-mCherry mice treated with DT. The number of GFAP-expressing cells within 
the AAV infection area, as indicated by the mCherry expression, was significantly higher than that in the control mice $\left(F_{(2,14)}=10.380, p=0.008, \mathrm{~A}_{2 \mathrm{~A}} \mathrm{R}^{\mathrm{WT}}\right.$ NAc GFAPDTR/DT vs $\mathrm{A}_{2 \mathrm{~A}} \mathrm{R}^{\mathrm{WT}}$ NAc GFAP-DTR/saline; $F_{(2,14)}=10.380, p=0.001, \mathrm{~A}_{2 \mathrm{~A}} \mathrm{R}^{\mathrm{WT}} \mathrm{NAc}$ GFAP-DTR/DT vs $\mathrm{A}_{2 \mathrm{~A}} \mathrm{R}^{\mathrm{WT}}$ NAc GFAP-mCherry/DT, Fig. 8g).

Because we observed an unexpected increase in GFAP expression after cytotoxic ablation of NAc GFAP-positive cells, we also examined the morphology of microglia in $\mathrm{A}_{2 \mathrm{~A}} \mathrm{R}^{\mathrm{WT}}$ NAc GFAP-DTR mice by immunohistochemical analysis with an antibody against the microglia marker TMEM119 (Fig. 8h, i). Activated microglia were detected in DT-treated $\mathrm{A}_{2 \mathrm{~A}} \mathrm{R}^{\mathrm{WT}}$ NAc GFAP-DTR mice (Fig. 8i), but not in DT-treated $\mathrm{A}_{2 \mathrm{~A}} \mathrm{R}^{\mathrm{WT}}$ NAc GFAP-mCherry mice. This observation suggests DT-mediated apoptosis of GFAP cells in the NAc is accompanied by microglia activation. 

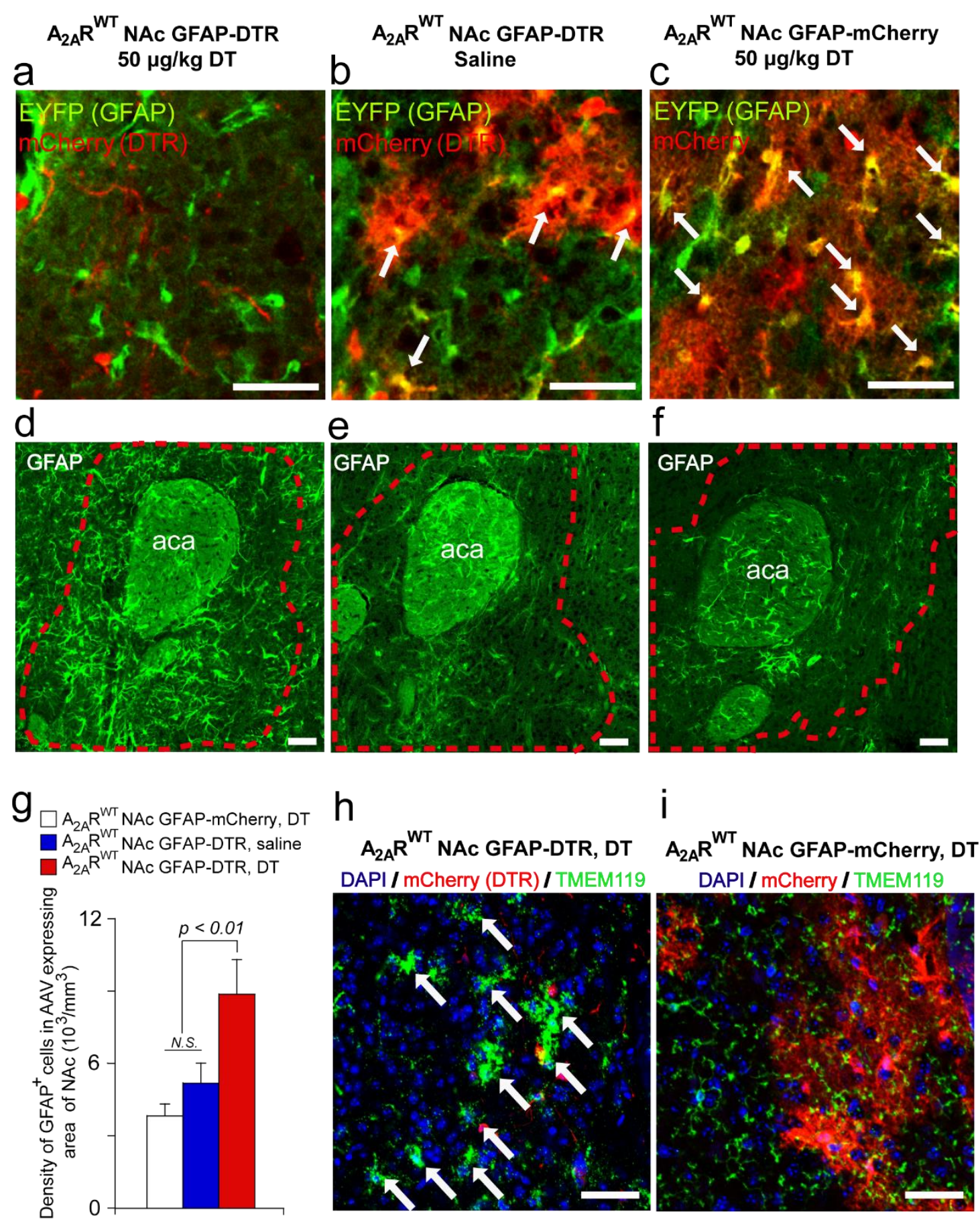

DAPI/ mCherry / TMEM119

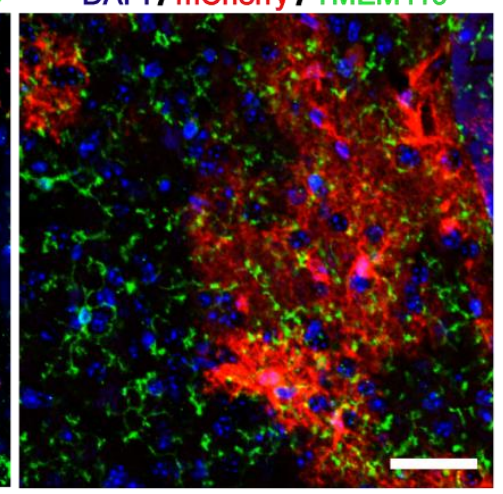

Figure 8. The number of GFAP-expressing cells is increased and microglia are activated after cytotoxic ablation of NAc GFAP-positive cells. a-c AAV-infected cells are destroyed in DT-treated $\mathrm{A}_{2 \mathrm{~A}} \mathrm{R}^{\mathrm{WT}}$ NAc GFAP-DTR mice (a) but not in saline-treated $\mathrm{A}_{2 \mathrm{~A}} \mathrm{R}^{\mathrm{WT}}$ NAc GFAP-DTR (b) or DT-treated $\mathrm{A}_{2 \mathrm{~A}} \mathrm{R}^{\mathrm{WT}}$ NAc GFAP-mCherry mice (c) on day 7 after DT injection. White arrows indicate AAV-infected astrocytes. Scale bars: 50 $\mu \mathrm{m}$. d-f Increased number of GFAP-positive cells in DT-treated $\mathrm{A}_{2 \mathrm{~A}} \mathrm{R}^{\mathrm{WT}}$ NAc GFAPDTR (d) compared with saline-treated $\mathrm{A}_{2 \mathrm{~A}} \mathrm{R}^{\mathrm{WT}}$ NAc GFAP-DTR (e) or DT-treated $\mathrm{A}_{2 \mathrm{~A}} \mathrm{R}^{\mathrm{WT}}$ NAc GFAP-mCherry mice (f). Scale bars: $50 \mu \mathrm{m}$. Red dashed lines indicate area with mCherry expression. $\mathbf{g}$ Number of GFAP-positive cells (astrocytes) in the AAV-infected area on day 7 after DT treatment in $\mathrm{A}_{2 \mathrm{~A}} \mathrm{R}^{\mathrm{WT}}$ NAc GFAP-DTR/DT $(n=6)$, 
$\mathrm{A}_{2 \mathrm{~A}} \mathrm{R}^{\mathrm{WT}}$ NAc GFAP-DTR/saline $(n=5)$ and $\mathrm{A}_{2 \mathrm{~A}} \mathrm{R}^{\mathrm{WT}}$ NAc GFAP-mCherry/DT $(n=6)$ mice. Significance was assessed by one-way ANOVA followed by the PLSD test. $\mathbf{h}, \mathbf{i}$ Immunostaining of activated or ramified microglia in $\mathrm{A}_{2 \mathrm{~A}} \mathrm{R}^{\mathrm{WT}}$ NAc GFAP-DTR (h) or $\mathrm{A}_{2 \mathrm{~A}} \mathrm{R}^{\mathrm{WT}}$ NAc GFAP-mCherry mice (i), respectively, after DT treatment. White arrows indicate activated/phagocytic microglia in the NAc. Scale bars: $40 \mu \mathrm{m}$.

\subsection{Extracellular adenosine levels increased after ablation of NAc GFAP-positive cells}

Finally, we investigated extracellular adenosine levels on day 7 after DT treatment using microdialysis (Fig. 9a, b). The dialysates were collected between 19:00 and 22:00 when there is a large increase in SWS and analyzed by HPLC. Dialysates were collected before and after DT treatment by inserting the same probe in contralateral sites of the mouse brain. The adenosine concentration was determined by comparison with adenosine standards (Fig. 9c) and normalized between the samples taken before and after DT treatment due to the varying recovery rates of the microdialysis probes. The position of the microdialysis probe was confirmed by immunohistochemical analysis of the expression of the AAV reporter protein mCherry (Fig. 9d).

Adenosine levels increased significantly after DT administration in $\mathrm{A}_{2 \mathrm{~A}} \mathrm{R}^{\mathrm{WT}}$ and $\mathrm{A}_{2 \mathrm{~A}} \mathrm{R}^{\mathrm{KO}}$ NAc GFAP-DTR mice, compared with $\mathrm{A}_{2 \mathrm{~A}} \mathrm{R}^{\mathrm{WT}}$ NAc GFAP-mCherry mice

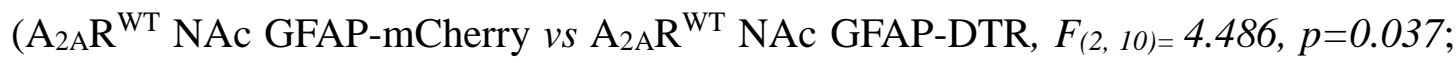
$\mathrm{A}_{2 \mathrm{~A}} \mathrm{R}^{\mathrm{WT}}$ NAc GFAP-mCherry $v s \mathrm{~A}_{2 \mathrm{~A}} \mathrm{R}^{\mathrm{KO}}$ NAc GFAP-DTR, $F_{(2,10)=4.486, p=0.019}$; Fig. 9e). These findings suggest that ablation of GFAP-positive cells in the NAc results in an increase in extracellular adenosine, at least on day 7 after cell apoptosis is initiated by DT treatment. 


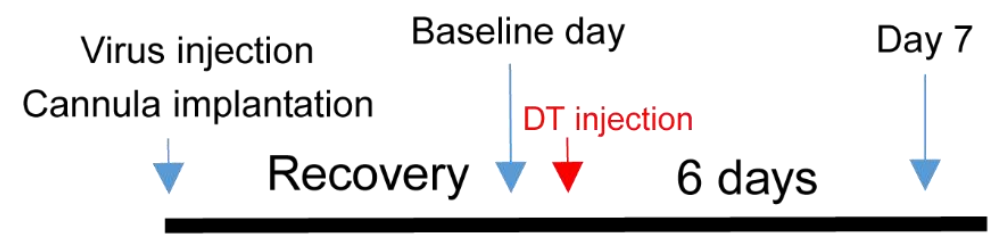

b
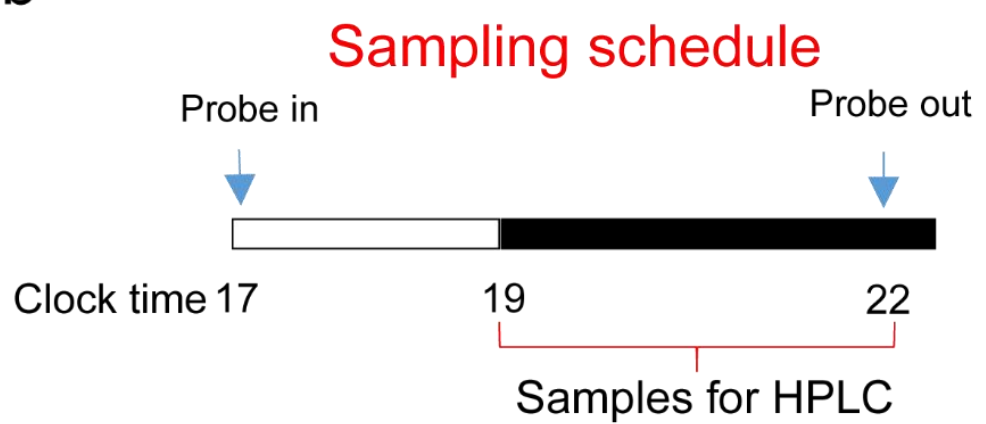

C

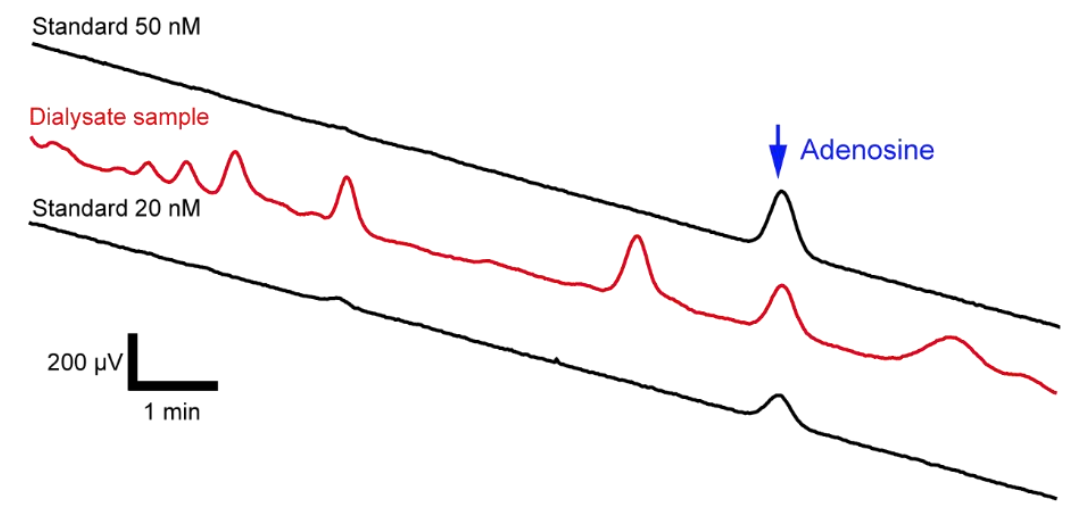

d

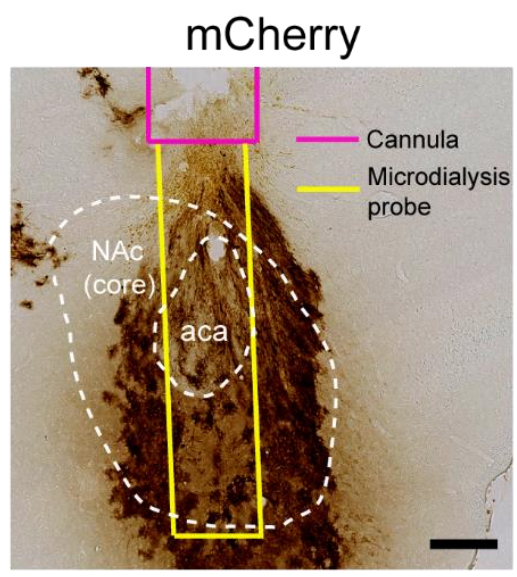

e

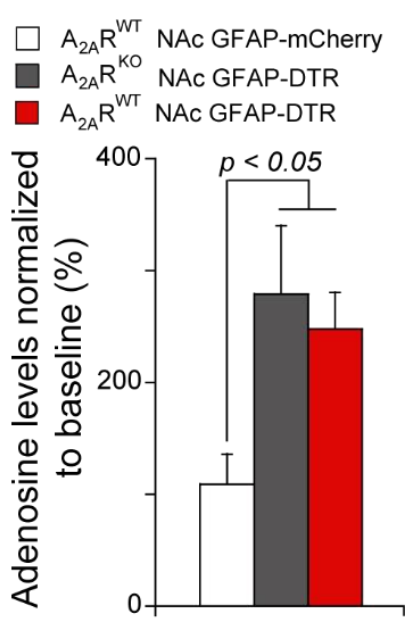

Figure 9. Measurement of extracellular adenosine levels in the NAc by microdialysis. a Microdialysis schedule before and after DT treatment. b Sampling schedule after inserting the microdialysis probe. c Typical HPLC chromatograms of a dialysate and external adenosine standards. d Typical implantation site for the guide cannula and 
location of the microdialysis probe in the NAc. Immunostaining for mCherry indicates the AAV-infected area in the NAc. Scale bar: $200 \mu \mathrm{m}$. e Extracellular adenosine levels normalized to baseline in the NAc of $\mathrm{A}_{2 \mathrm{~A}} \mathrm{R}^{\mathrm{WT}} \mathrm{NAc}$ GFAP-mCherry $(\mathrm{n}=4), \mathrm{A}_{2 \mathrm{~A}} \mathrm{R}^{\mathrm{WT}} \mathrm{NAc}$ GFAP-DTR $(n=5)$, and $A_{2 A} R^{K O}$ NAc GFAP-DTR $(n=4)$ mice on day 7 after treatment with $50 \mu \mathrm{g} / \mathrm{kg}$ DT. Significance was assessed by one-way ANOVA followed by the PLSD test.

\section{Discussion}

A recent study showed that chemogenetic or optogenetic activation of NAc core $A_{2 A} R$ neurons projecting to the ventral pallidum strongly induces SWS, whereas chemogenetic inhibition of these neurons prevents sleep induction, but does not affect the homoeostatic sleep rebound (Oishi et al., 2017). We hypothesized that adenosine is a candidate molecule for activating NAc $\mathrm{A}_{2 \mathrm{~A}} \mathrm{R}$ neurons. Where in the NAc adenosine is generated, however, remains unknown. Adenosine is not a neurotransmitter or a typical neuromodulator released from neurons, because it can be formed by various processes in all cell types (Ohana et al., 2001). Cytotoxic ablation of GFAP-positive cells, which are likely astrocytes, as well as a small number of neurons in the NAc led to a transient increase in SWS over several days in mice. Further analysis of the molecular mechanisms revealed that extracellular adenosine levels increased after ablation and the SWS increase was mediated by $\mathrm{A}_{2 \mathrm{~A}} \mathrm{R}$.

Surprisingly, the number of astrocytes in the NAc core was also increased after GFAPpositive cell ablation. The increase in the number of astrocytes may be due to astrogliosis, i.e., astrocyte migration or proliferation, after apoptotic destruction of astrocytes or neurons by DT (Aldskogius \& Kozlova, 1998; Morimoto \& Bonavida, 1992). We suspect that the increase in extracellular adenosine is due to the increased 
number of astrocytes. A role for astrocytes in sleep regulation has only recently started to emerge. Extracellular levels of adenosine and recovery sleep after sleep deprivation are reduced when the release of ATP is blocked by the transgenic expression of the dnSNARE protein in astrocytes (Chen \& Scheller, 2001; Halassa et al., 2009; Pascual et al., 2005; Raingo et al., 2012) and astrocytic adenosine kinase is involved in regulating homeostatic sleep (Bjorness et al., 2016). Moreover, optogenetic stimulation of astrocytes in the posterior hypothalamus increases sleep (Pelluru et al., 2016).

The possibility that activated microglia also contribute to the elevated adenosine levels cannot be excluded. Microglia are immune cells distributed throughout the brain, comprising $10 \%$ to $20 \%$ of the glial population (Ginhoux et al., 2013). Microglia in a phagocytic state are usually involved in the clearance of apoptotic cells (Lian et al., 2016). The role of microglia in sleep regulation remains elusive. Some studies reported that microglia are activated after sleep deprivation (Huang et al., 2014; Wadhwa et al., 2018; Wisor et al., 2011). Microglia activation is likely a consequence of sleep loss, however, rather than the cause of sleep rebound. Microglia are considered to be a major source of cytokines, but there is almost no evidence indicating that microglia can release adenosine (Hanisch, 2002; Smith et al., 2012). In contrast, adenosine has an important role in regulating microglia via adenosine receptors (Gyoneva et al., 2009; Luongo et al., 2014; Madeira et al., 2018; Orr et al., 2009). Future studies utilizing opto- or chemogenetic systems are needed to examine the ability of microglia to release adenosine and induce sleep. Moreover, cytokines have a known role in sleep/wake regulation, but the effects of cytokines released from microglia in the NAc on sleep 
have never been investigated. The $\mathrm{A}_{2 \mathrm{~A}} \mathrm{R}^{\mathrm{KO}} \mathrm{NAc}$ GFAP-DTR mice exhibited no increase in SWS after DTR-mediated ablation of astrocytes and neurons, suggesting that cytokines are not involved in the sleep phenotype.

Moreover, the DTR was also expressed in neurons to some extent due to leakage of the GFAP promoter used in our viral vector and thus, it is possible that we also ablated a small number of neurons by DT administration. We do not consider this directly relevant, however, because the sleep/wake behavior of $\mathrm{A}_{2 \mathrm{~A}} \mathrm{R}^{\mathrm{KO}}$ mice is not affected by DTR-mediated ablation of astrocytes and neurons, and cytotoxic lesions of the NAc core or shell neurons induce wakefulness (Qiu et al., 2012). Neuronal ablation, however, may contribute to activate the astrocytes and microglia (Aldskogius and Kozlova, 1998). Strong reactivation of astrocytes and microglia in healthy mammalians is not a common phenomenon but usually it can be observed in brains with inflammation or injuries. Therefore, the cytotoxic ablation of astrocytes and neurons may mimic traumatic brain injury (TBI) which is often associated with sleep disorders. TBI patients experience high rates of insomnia (29\%), hypersomnia (28\%), and sleep apnea (25\%) (Wickwire et al., 2016). For example, hypersomnia was observed in patients with thalamic astrogliosis and increased adenosine levels in the cerebral spinal fluid during an acute period after TBI (Hazra et al., 2014; Rowe et al., 2014; Zuzuárregui et al., 2018). An imbalance of neurotransmitters (e.g., GABA, glutamate and orexin) or increased cytokine production in the hypothalamus or brain stem after TBI, however, is believed to cause the sleep disturbance (Sandsmark et al., 2017). Although adenosine is known 
to play an important role in neuroprotection after TBI (Lusardi, 2009), the involvement of adenosine, especially in the NAc, in TBI-related sleep disorders remains unclear.

\section{Conclusion}

Activation of $A_{2 A} R$ neurons in the NAc core promotes SWS sleep and elevated adenosine levels in the NAc core increase SWS by acting on $\mathrm{A}_{2 \mathrm{~A}} \mathrm{R}$. Our findings provide the first evidence that adenosine is a strong candidate molecule for activating NAc core $A_{2 A} R$ neurons to induce SWS.

\section{Acknowledgements}

I give special thanks to my family members for their essential supports and patience through the past 4 years of study.

I express my gratitude to Dr. Michael Lazarus for his professional instructions, generous experimental supports and rigid supervision. I also feel thankful to the other Lazarus lab members especially the Phd students who helped me a lot and grew up together with me.

\section{Reference}

Aldskogius, H., \& Kozlova, E. N. (1998). Central neuron-glial and glial-glial interactions following axon injury. Prog Neurobiol, 55(1), 1-26.

Ballarin, M., Fredholm, B. B., Ambrosio, S., \& Mahy, N. (1991). Extracellular levels of adenosine and its metabolites in the striatum of awake rats: inhibition of uptake and metabolism. Acta Physiol Scand, 142(1), 97-103. 
Basheer, R., Porkka-Heiskanen, T., Strecker, R. E., Thakkar, M. M., \& McCarley, R. W. (2000). Adenosine as a biological signal mediating sleepiness following prolonged wakefulness. Biol Signals Recept, 9(6), 319-327.

Basheer, R., Halldner, L., Alanko, L., McCarley, R. W., Fredholm, B. B., \& PorkkaHeiskanen, T. (2001). Opposite changes in adenosine A(1) and A(2A) receptor mRNA in the rat following sleep deprivation. Neuroreport, 12(8), 1577-1580.

Bell, C. E., \& Eisenberg, D. (1996). Crystal structure of diphtheria toxin bound to nicotinamide adenine dinucleotide. Biochemistry, 35(4), 1137-1149.

Benington, J. H., Kodali, S. K., \& Heller, H. C. (1995). Stimulation of A1 adenosine receptors mimics the electroencephalographic effects of sleep deprivation. Brain Res, 692(1-2), 79-85.

Bjorness, T. E., Kelly, C. L., Gao, T. S., Poffenberger, V., \& Greene, R. W. (2009). Control and Function of the Homeostatic Sleep Response by Adenosine A(1) Receptors. J Neurosci, 29(5), 1267-1276.

Bjorness, T. E., Dale, N., Mettlach, G., Sonneborn, A., Sahin, B., Fienberg, A. A., Yanagisawa, M., Bibb, J.A., \& Greene, R. W. (2016). An Adenosine-Mediated Glial-Neuronal Circuit for Homeostatic Sleep. J Neurosci, 36(13), 3709-3721.

Blum, K., Werner, T., Carnes, S., Carnes, P., Bowirrat, A., Giordano, J., Oscar-Berman M., \& Gold, M. (2012). Sex, drugs, and rock 'n' roll: hypothesizing common mesolimbic activation as a function of reward gene polymorphisms. $J$ Psychoactive Drugs, 44(1), 38-55.

Britt, J. P., Benaliouad, F., McDevitt, R. A., Stuber, G. D., Wise, R. A., \& Bonci, A. 
(2012). Synaptic and behavioral profile of multiple glutamatergic inputs to the nucleus accumbens. Neuron, 76(4), 790-803.

Brockschnieder, D., Lappe-Siefke, C., Goebbels, S., Boesl, M. R., Nave, K. A., \& Riethmacher, D. (2004). Cell depletion due to diphtheria toxin fragment A after Cre-mediated recombination. Mol Cell Biol, 24(17), 7636-7642.

Brog, J. S., Salyapongse, A., Deutch, A. Y., \& Zahm, D. S. (1993). The patterns of afferent innervation of the core and shell in the "accumbens" part of the rat ventral striatum: immunohistochemical detection of retrogradely transported fluoro-gold. J Comp Neurol, 338(2), 255-278.

Brooks, G. A. (2009). Cell-cell and intracellular lactate shuttles. J Physiol, 587(Pt 23), $5591-5600$.

Chamberlin, N. L., Du, B., de Lacalle, S., \& Saper, C. B. (1998). Recombinant adenoassociated virus vector: use for transgene expression and anterograde tract tracing in the CNS. Brain Res, 793(1-2), 169-175.

Chang, T., \& Neville, D. M., Jr. (1978). Demonstration of diphtheria toxin receptors on surface membranes from both toxin-sensitive and toxin-resistant species. J Biol Chem, 253(19), 6866-6871.

Chen, J. F., Huang, Z., Ma, J., Zhu, J., Moratalla, R., Standaert, D., Moskowitz, M.A., Fink, J.S., \& Schwarzschild, M. A. (1999). A(2A) adenosine receptor deficiency attenuates brain injury induced by transient focal ischemia in mice. $J$ Neurosci, 19(21), 9192-9200.

Chen, Y. A., \& Scheller, R. H. (2001). Snare-mediated membrane fusion. Nat Rev Mol 
Cell Biol, 2(2), 98-106.

Cunha, R. A. (2001). Adenosine as a neuromodulator and as a homeostatic regulator in the nervous system: different roles, different sources and different receptors. Neurochem Int, 38(2), 107-125.

Daly, J. W., \& Padgett, W. L. (1992). Agonist Activity of 2-Substituted and 5'Substituted Adenosine-Analogs and Their N6-Cycloalkyl Derivatives at Adenosine-A1 and Adenosine-A2 Receptors Coupled to Adenylate-Cyclase. Biochem Pharmacol, 43(5), 1089-1093.

Dispersyn, G., Sauvet, F., Gomez-Merino, D., Ciret, S., Drogou, C., Leger, D., Gallopin, T., \& Chennaoui, M. (2017). The homeostatic and circadian sleep recovery responses after total sleep deprivation in mice. J Sleep Res, 26(5), 531-538.

Drury, A. N., \& Szent-Gyorgyi, A. (1929). The physiological activity of adenine compounds with especial reference to their action upon the mammalian heart. $J$ Physiol, 68(3), 213-237.

Dunwiddie, T. V., \& Worth, T. (1982). Sedative and Anticonvulsant Effects of Adenosine-Analogs in Mouse and Rat. J Pharmacol Exp Ther, 220(1), 70-76.

Feldberg, W., \& Sherwood, S. L. (1954). Injections of drugs into the lateral ventricle of the cat. J Physiol, 123(1), 148-167.

Fredholm, B. B., Ijzerman, A. P., Jacobson, K. A., Klotz, K. N., \& Linden, J. (2001). International Union of Pharmacology. XXV. Nomenclature and classification of adenosine receptors. Pharmacol Rev, 53(4), 527-552. 
Fredholm, B. B., Chen, J. F., Cunha, R. A., Svenningsson, P., \& Vaugeois, J. M. (2005). Adenosine and brain function. Int Rev Neurobiol, 63, 191-270.

Fredholm, B. B. (2007). Adenosine, an endogenous distress signal, modulates tissue damage and repair. Cell Death Differ, 14(7), 1315-1323.

Fredholm, B. B., AP, I. J., Jacobson, K. A., Linden, J., \& Muller, C. E. (2011). International Union of Basic and Clinical Pharmacology. LXXXI. Nomenclature and classification of adenosine receptors--an update. Pharmacol Rev, 63(1), 1-34.

Garcia, A. D., Doan, N. B., Imura, T., Bush, T. G., \& Sofroniew, M. V. (2004). GFAPexpressing progenitors are the principal source of constitutive neurogenesis in adult mouse forebrain. Nat Neurosci, 7(11), 1233-1241.

George Paxinos, \& Keith Franklin. (2001). The Mouse Brain in Stereotaxic Coordinates. 2nd edn. Academic Press.

Ginhoux, F., Lim, S., Hoeffel, G., Low, D., \& Huber, T. (2013). Origin and differentiation of microglia. Front Cell Neurosci, 7, 45.

Gipson, C. D., Kupchik, Y. M., \& Kalivas, P. W. (2014). Rapid, transient synaptic plasticity in addiction. Neuropharmacol, 76 Pt B, 276-286.

Goto, Y., \& O'Donnell, P. (2001). Synchronous activity in the hippocampus and nucleus accumbens in vivo. $J$ Neurosci, 21(4), RC131.

Gyoneva, S., Orr, A. G., \& Traynelis, S. F. (2009). Differential regulation of microglial motility by ATP/ADP and adenosine. Parkinsonism Relat Disord, 15 Suppl 3, S195-199. 
Haas, H., \& Panula, P. (2003). The role of histamine and the tuberomamillary nucleus in the nervous system. Nat Rev Neurosci, 4(2), 121-130.

Halassa, M. M., Florian, C., Fellin, T., Munoz, J. R., Lee, S. Y., Abel, T., Haydon, P.G., \& Frank, M. G. (2009). Astrocytic Modulation of Sleep Homeostasis and Cognitive Consequences of Sleep Loss. Neuron, 61(2), 213-219.

Hanisch, U. K. (2002). Microglia as a source and target of cytokines. Glia, 40(2), 140155.

Haulica, I., Ababei, L., Branisteanu, D., Braniste.D, \& Topoliceanu, F. (1973). Preliminary Data on Possible Hypnogenic Role of Adenosine. J Neurochem, 21(4), 1019-1020.

Hazra, A., Macolino, C., Elliott, M. B., \& Chin, J. (2014). Delayed thalamic astrocytosis and disrupted sleep-wake patterns in a preclinical model of traumatic brain injury. J Neurosci Res, 92(11), 1434-1445.

Honjo, T., Nishizuka, Y., \& Hayaishi, O. (1968). Diphtheria toxin-dependent adenosine diphosphate ribosylation of aminoacyl transferase II and inhibition of protein synthesis. J Biol Chem, 243(12), 3553-3555.

Huang, C. T., Chiang, R. P., Chen, C. L., \& Tsai, Y. J. (2014). Sleep deprivation aggravates median nerve injury-induced neuropathic pain and enhances microglial activation by suppressing melatonin secretion. Sleep, 37(9), 15131523.

Huang, Z. L., Qu, W. M., Eguchi, N., Chen, J. F., Schwarzschild, M. A., Fredholm, B. B., Urade, Y., \& Hayaishi, O. (2005). Adenosine A2A, but not A1, receptors 
mediate the arousal effect of caffeine. Nat Neurosci, 8(7), 858-859.

Huston, J. P., Haas, H. L., Boix, F., Pfister, M., Decking, U., Schrader, J., \& Schwarting, R. K. W. (1996). Extracellular adenosine levels in neostriatum and hippocampus during rest and activity periods of rats. Neuroscience, 73(1), 99-107.

Inagaki, N., Yamatodani, A., Ando-Yamamoto, M., Tohyama, M., Watanabe, T., \& Wada, H. (1988). Organization of histaminergic fibers in the rat brain. J Comp Neurol, 273(3), 283-300.

Iwasaki, K., Komiya, H., Kakizaki, M., Miyoshi, C., Abe, M., Sakimura, K., Funato, H., \& Yanagisawa, M. (2018). Ablation of Central Serotonergic Neurons Decreased REM Sleep and Attenuated Arousal Response. Front Neurosci, 12, 535.

Joel, D., \& Weiner, I. (2000). The connections of the dopaminergic system with the striatum in rats and primates: an analysis with respect to the functional and compartmental organization of the striatum. Neuroscience, 96(3), 451-474.

Kalinchuk, A. V., Urrila, A.-S., Alanko, L., Heiskanen, S., Wigren, H.-K., Suomela, M., Stenberg, D., \& Porkka-Heiskanen, T. (2003). Local energy depletion in the basal forebrain increases sleep. Eur J Neurosci, 17(4), 863-869.

Kimata, Y., \& Kohno, K. (1994). Elongation factor 2 mutants deficient in diphthamide formation show temperature-sensitive cell growth. J Biol Chem, 269(18), 13497-13501.

Kohlschutter, J., Michelfelder, S., \& Trepel, M. (2010). Novel cytotoxic vectors based on adeno-associated virus. Toxins (Basel), 2(12), 2754-2768. 
Kohno, K., Uchida, T., Ohkubo, H., Nakanishi, S., Nakanishi, T., Fukui, T., Ohtsuka, E., Ikehara, M., \& Okada, Y. (1986). Amino acid sequence of mammalian elongation factor 2 deduced from the cDNA sequence: homology with GTPbinding proteins. Proc Natl Acad Sci U S A, 83(14), 4978-4982.

Kohno, K., \& Uchida, T. (1987). Highly frequent single amino acid substitution in mammalian elongation factor 2 (EF-2) results in expression of resistance to EF2-ADP-ribosylating toxins. J Biol Chem, 262(25), 12298-12305.

Kohtoh, S., Taguchi, Y., Matsumoto, N., Wada, M., Huang, Z. L., \& Urade, Y. (2008). Algorithm for sleep scoring in experimental animals based on fast Fourier transform power spectrum analysis of the electroencephalogram. Sleep and Biological Rhythms, 6(3), 163-171.

Kovacs, Z., Dobolyi, A., Kekesi, K. A., \& Juhasz, G. (2013). 5'-nucleotidases, nucleosides and their distribution in the brain: pathological and therapeutic implications. Curr Med Chem, 20(34), 4217-4240.

Latini, S., \& Pedata, F. (2001). Adenosine in the central nervous system: release mechanisms and extracellular concentrations. J Neurochem, 79(3), 463-484.

Lazarus, M., Shen, H.Y., Cherasse, Y., Qu, W.M., Huang, Z.L., Bass, C. E., WinskySommerer, R., Semba, K., Fredholm, B.B., Boison, D., Hayaishi, O., Urade, Y., \& Chen, J.F. (2011). Arousal effect of caffeine depends on adenosine A2A receptors in the shell of the nucleus accumbens. J Neurosci, 31(27), 1006710075.

Lazarus, M., Chen, J. F., Huang, Z. L., Urade, Y., \& Fredholm, B. B. (2017). Adenosine 
and Sleep. Handb Exp Pharmacol.

Lee, H. J., Weitz, A. J., Bernal-Casas, D., Duffy, B. A., Choy, M., Kravitz, A. V., Kreitzer, A. C., \& Lee, J. H. (2016). Activation of Direct and Indirect Pathway Medium Spiny Neurons Drives Distinct Brain-wide Responses. Neuron, 91(2), 412-424.

Lian, H., Roy, E., \& Zheng, H. (2016). Microglial Phagocytosis Assay. Bio Protoc, $6(21)$.

Linden, J., Taylor, H. E., Robeva, A. S., Tucker, A. L., Stehle, J. H., Rivkees, S. A., Fink, J.S., \& Reppert, S. M. (1993). Molecular cloning and functional expression of a sheep A3 adenosine receptor with widespread tissue distribution. Mol Pharmacol, 44(3), 524-532.

Luo, Y. J., Li, Y. D., Wang, L., Yang, S. R., Yuan, X. S., Wang, J., Cherasse, Y., Lazarus, M., Chen, J.F., Qu, W.M., \& Huang, Z. L. (2018). Nucleus accumbens controls wakefulness by a subpopulation of neurons expressing dopamine D1 receptors. Nat Commun, 9(1), 1576.

Luongo, L., Guida, F., Imperatore, R., Napolitano, F., Gatta, L., Cristino, L., Giordano, C., Siniscalco, D., Di Marzo, V., Bellini, G., Petrelli, R., Cappellacci, L., Usiello, A., de Novellis, V., Rossi, F., \& Maione, S. (2014). The A1 adenosine receptor as a new player in microglia physiology. Glia, 62(1), 122-132.

Lusardi, T. A. (2009). Adenosine neuromodulation and traumatic brain injury. Curr Neuropharmacol, 7(3), 228-237.

Lynd-Balta, E., \& Haber, S. N. (1994). The organization of midbrain projections to the 
ventral striatum in the primate. Neuroscience, 59(3), 609-623.

Madeira, M. H., Rashid, K., Ambrosio, A. F., Santiago, A. R., \& Langmann, T. (2018). Blockade of microglial adenosine A2A receptor impacts inflammatory mechanisms, reduces ARPE-19 cell dysfunction and prevents photoreceptor loss in vitro. Sci Rep, 8(1), 2272.

Malenka, R., Nestler, E., \& Hyman, S. (2009). Chapter 6: Widely Projecting Systems: Monoamines, Acetylcholine, and Orexin. Molecular Neuropharmacol: A Foundation for Clinical Neuroscience (2nd ed.), 175-176.

Marley, E., \& Nistico, G. (1972). Effects of Catecholamines and Adenosine Derivatives Given into Brain of Fowls. Br J Pharmacol, 46(4), 619-636.

Mitamura, T., Higashiyama, S., Taniguchi, N., Klagsbrun, M., \& Mekada, E. (1995). Diphtheria toxin binds to the epidermal growth factor (EGF)-like domain of human heparin-binding EGF-like growth factor/diphtheria toxin receptor and inhibits specifically its mitogenic activity. J Biol Chem, 270(3), 1015-1019.

Morimoto, H., \& Bonavida, B. (1992). Diphtheria toxin- and Pseudomonas A toxinmediated apoptosis. ADP ribosylation of elongation factor-2 is required for DNA fragmentation and cell lysis and synergy with tumor necrosis factor-alpha. J Immunol, 149(6), 2089-2094.

Nam, H. W., Bruner, R. C., \& Choi, D. S. (2013). Adenosine signaling in striatal circuits and alcohol use disorders. Mol Cells, 36(3), 195-202.

Ohana, G., Bar-Yehuda, S., Barer, F., \& Fishman, P. (2001). Differential effect of adenosine on tumor and normal cell growth: focus on the A3 adenosine receptor. 
J Cell Physiol, 186(1), 19-23.

Oishi, Y., Huang, Z. L., Fredholm, B. B., Urade, Y., \& Hayaishi, O. (2008). Adenosine in the tuberomammillary nucleus inhibits the histaminergic system via A1 receptors and promotes non-rapid eye movement sleep. Proc Natl Acad Sci U S A, 105(50), 19992-19997.

Oishi, Y., Takata, Y., Taguchi, Y., Kohtoh, S., Urade, Y., \& Lazarus, M. (2016). Polygraphic Recording Procedure for Measuring Sleep in Mice. J Vis Exp(107), e53678.

Oishi, Y., Xu, Q., Wang, L., Zhang, B. J., Takahashi, K., Takata, Y., Luo, Y.J., Cherasse, Y., Schiffmann, S.N., de Kerchove d'Exaerde, A., Urade, Y., Qu, W.M., Huang, Z.L., \& Lazarus, M. (2017). Slow-wave sleep is controlled by a subset of nucleus accumbens core neurons in mice. Nat Commun, 8(1), 734.

Okada, T., Mochizuki, T., Huang, Z. L., Eguchi, N., Sugita, Y., Urade, Y., \& Hayaishi, O. (2003). Dominant localization of adenosine deaminase in leptomeninges and involvement of the enzyme in sleep. Biochem Biophys Res Commun, 312(1), 29-34.

Orr, A. G., Orr, A. L., Li, X. J., Gross, R. E., \& Traynelis, S. F. (2009). Adenosine A(2A) receptor mediates microglial process retraction. Nat Neurosci, 12(7), 872-878.

Paes-de-Carvalho, R. (2002). Adenosine as a signaling molecule in the retina: biochemical and developmental aspects. An Acad Bras Cienc, 74(3), 437-451.

Palmiter, R. D., Behringer, R. R., Quaife, C. J., Maxwell, F., Maxwell, I. H., \& Brinster, R. L. (1987). Cell lineage ablation in transgenic mice by cell-specific expression 
of a toxin gene. Cell, 50(3), 435-443.

Parkinson, F. E., Damaraju, V. L., Graham, K., Yao, S. Y., Baldwin, S. A., Cass, C. E., \& Young, J. D. (2011). Molecular biology of nucleoside transporters and their distributions and functions in the brain. Curr Top Med Chem, 11(8), 948-972.

Pascual, O., Casper, K. B., Kubera, C., Zhang, J., Revilla-Sanchez, R., Sul, J. Y., Takano, H., Moss, S. J., McCarthy, K., \& Haydon, P. G. (2005). Astrocytic purinergic signaling coordinates synaptic networks. Science, 310(5745), 113-116.

Pekny, M., Leveen, P., Pekna, M., Eliasson, C., Berthold, C. H., Westermark, B., \& Betsholtz, C. (1995). Mice lacking glial fibrillary acidic protein display astrocytes devoid of intermediate filaments but develop and reproduce normally. EMBO J, 14(8), 1590-1598.

Pekny, M., \& Pekna, M. (2004). Astrocyte intermediate filaments in CNS pathologies and regeneration. J Pathol, 204(4), 428-437.

Pelluru, D., Konadhode, R. R., Bhat, N. R., \& Shiromani, P. J. (2016). Optogenetic stimulation of astrocytes in the posterior hypothalamus increases sleep at night in C57BL/6J mice. Eur J Neurosci, 43(10), 1298-1306.

Porkka-Heiskanen, T., Strecker, R. E., Thakkar, M., Bjorkum, A. A., Greene, R. W., \& McCarley, R. W. (1997). Adenosine: a mediator of the sleep-inducing effects of prolonged wakefulness. Science., 276(5316), 1265-1268.

Porkka-Heiskanen, T., Strecker, R. E., \& McCarley, R. W. (2000). Brain site-specificity of extracellular adenosine concentration changes during sleep deprivation and spontaneous sleep: an in vivo microdialysis study. Neuroscience, 99(3), 507- 
Pull, I., \& Mcilwain, H. (1972). Metabolism of [C-14] Adenine and Derivatives by Cerebral Tissues, Superfused and Electrically Stimulated. Biochem J, 126(4), 965-973.

Qiu, M. H., Liu, W., Qu, W. M., Urade, Y., Lu, J., \& Huang, Z. L. (2012). The role of nucleus accumbens core/shell in sleep-wake regulation and their involvement in modafinil-induced arousal. PLoS One, 7(9), e45471.

Radulovacki, M., Virus, R. M., Djuricicnedelson, M., \& Green, R. D. (1983). Hypnotic Effects of Deoxycorformycin in Rats. Brain Res, 271(2), 392-395.

Radulovacki, M., Virus, R. M., Djuricicnedelson, M., \& Green, R. D. (1984). Adenosine-Analogs and Sleep in Rats. J Pharmacol Exp Ther, 228(2), 268-274.

Radulovacki, M., Virus, R. M., Rapoza, D., \& Crane, R. A. (1985). A Comparison of the Dose-Response Effects of Pyrimidine Ribonucleosides and Adenosine on Sleep in Rats. Psychopharmacol, 87(2), 136-140.

Raingo, J., Khvotchev, M., Liu, P., Darios, F., Li, Y. C., Ramirez, D. M., Adachi, M., Lemieux, P., Toth, K., Davletov, B., \& Kavalali, E. T. (2012). VAMP4 directs synaptic vesicles to a pool that selectively maintains asynchronous neurotransmission. Nat Neurosci, 15(5), 738-745.

Ren, S., Wang, Y., Yue, F., Cheng, X., Dang, R., Qiao, Q., Sun, X., Li, X., Jiang, Q., Yao, J., Qin, H., Wang, G., Liao, X., Gao, D., Xia, J., Zhang, J., Hu, B., Yan, J., Wang, Y., Xu, M., Han, Y., Tang, X., Chen, X., He, C., \& Hu, Z. (2018). The paraventricular thalamus is a critical thalamic area for wakefulness. Science, 
$362(6413), 429-434$.

Robinson, E. A., Henriksen, O., \& Maxwell, E. S. (1974). Elongation factor 2. Amino acid sequence at the site of adenosine diphosphate ribosylation. $J$ Biol Chem, 249(16), 5088-5093.

Robison, A. J., \& Nestler, E. J. (2011). Transcriptional and epigenetic mechanisms of addiction. Nat Rev Neurosci, 12(11), 623-637.

Rowe, R. K., Striz, M., Bachstetter, A. D., Van Eldik, L. J., Donohue, K. D., O'Hara, B. F., \& Lifshitz, J. (2014). Diffuse brain injury induces acute post-traumatic sleep. PLoS One, 9(1), e82507. doi: 10.1371/journal.pone.0082507

Saito, M., Iwawaki, T., Taya, C., Yonekawa, H., Noda, M., Inui, Y., Mekada, E., Kimata, Y., Tsuru, A., \& Kohno, K. (2001). Diphtheria toxin receptor-mediated conditional and targeted cell ablation in transgenic mice. Nat Biotechnol, 19(8), 746-750.

Salvatore, C. A., Jacobson, M. A., Taylor, H. E., Linden, J., \& Johnson, R. G. (1993). Molecular cloning and characterization of the human A3 adenosine receptor. Proc Natl Acad Sci U S A, 90(21), 10365-10369.

Sandsmark, D. K., Elliott, J. E., \& Lim, M. M. (2017). Sleep-Wake Disturbances After Traumatic Brain Injury: Synthesis of Human and Animal Studies. Sleep, 40(5).

Schrader, J. (1983). Metabolism of Adenosine and Sites of Production in the Heart. In R. Berne, T. Rall \& R. Rubio (Eds.). Regulatory Function of Adenosine (Vol. 2, pp. 133-156): Springer US.

Smith, J. A., Das, A., Ray, S. K., \& Banik, N. L. (2012). Role of pro-inflammatory 
cytokines released from microglia in neurodegenerative diseases. Brain Res Bull, 87(1), 10-20.

Sofroniew, M. V. (2009). Molecular dissection of reactive astrogliosis and glial scar formation. Trends Neurosci, 32(12), 638-647.

Sofroniew, M. V., \& Vinters, H. V. (2010). Astrocytes: biology and pathology. Acta Neuropathol, 119(1), 7-35.

Srinivas, S., Watanabe, T., Lin, C. S., William, C. M., Tanabe, Y., Jessell, T. M., \& Costantini, F. (2001). Cre reporter strains produced by targeted insertion of EYFP and ECFP into the ROSA26 locus. BMC Dev Biol, $1,4$.

Swanson, L. W. (1982). The Projections of the Ventral Tegmental Area and Adjacent Regions - a Combined Fluorescent Retrograde Tracer and Immunofluorescence Study in the Rat. Brain Res Bull, 9(1-6), 321-353.

Tellez, L. A., Perez, I. O., Simon, S. A., \& Gutierrez, R. (2012). Transitions between sleep and feeding states in rat ventral striatum neurons. J Neurophysiol, 108(6), $1739-1751$.

Ticho, S. R., \& Radulovacki, M. (1991). Role of Adenosine in Sleep and Temperature Regulation in the Preoptic Area of Rats. Pharmacol Biochem Behav, 40(1), 3340.

Tobler, I., \& Scherschlicht, R. (1990). Sleep and Eeg Slow-Wave Activity in the Domestic Cat - Effect of Sleep-Deprivation. Behav Brain Res, 37(2), 109-118.

Van Ness, B. G., Howard, J. B., \& Bodley, J. W. (1980). ADP-ribosylation of elongation factor 2 by diphtheria toxin. NMR spectra and proposed structures of ribosyl- 
diphthamide and its hydrolysis products. J Biol Chem, 255(22), 10710-10716.

Vanwylen, D. G. L., Park, T. S., Rubio, R., \& Berne, R. M. (1986). Increases in Cerebral Interstitial Fluid Adenosine Concentration during Hypoxia, Local Potassium Infusion, and Ischemia. J Cereb Blood Flow Metab, 6(5), 522-528.

Wada, H., Inagaki, N., Yamatodani, A., \& Watanabe, T. (1991). Is the histaminergic neuron system a regulatory center for whole-brain activity? Trends Neurosci, 14(9), 415-418.

Wadhwa, M., Chauhan, G., Roy, K., Sahu, S., Deep, S., Jain, V., Kishore, K., Ray, K., Thakur, L., \& Panjwani, U. (2018). Caffeine and Modafinil Ameliorate the Neuroinflammation and Anxious Behavior in Rats during Sleep Deprivation by Inhibiting the Microglia Activation. Front Cell Neurosci, 12, 49.

Wang, Z., Ma, J., Miyoshi, C., Li, Y., Sato, M., Ogawa, Y., Lou, T., Ma, C., Gao, X., Lee, C., Fujiyama, T., Yang, X., Zhou, S., Hotta-Hirashima, N., KleweNebenius, D., Ikkyu, A., Kakizaki, M., Kanno, S., Cao, L., Takahashi, S., Peng, J., Yu, Y., Funato, H., Yanagisawa, M., \& Liu, Q. (2018). Quantitative phosphoproteomic analysis of the molecular substrates of sleep need. Nature, $558(7710), 435-439$.

Wickwire, E. M., Williams, S. G., Roth, T., Capaldi, V. F., Jaffe, M., Moline, M., Motamedi, G. K., Morgan, G. W., Mysliwiec, V., Germain, A., Pazdan, R. M., Ferziger, R., Balkin, T. J., MacDonald, M. E., Macek, T. A., Yochelson, M. R., Scharf, S. M., \& Lettieri, C. J. (2016). Sleep, Sleep Disorders, and Mild Traumatic Brain Injury. What We Know and What We Need to Know: Findings 
from a National Working Group. Neurotherapeutics, 13(2), 403-417.

Wisor, J. P., Schmidt, M. A., \& Clegern, W. C. (2011). Evidence for neuroinflammatory and microglial changes in the cerebral response to sleep loss. Sleep, 34(3), 261272.

Yamaizumi, M., Mekada, E., Uchida, T., \& Okada, Y. (1978). One molecule of diphtheria toxin fragment A introduced into a cell can kill the cell. Cell, 15(1), 245-250.

Yegutkin, G. G. (2008). Nucleotide- and nucleoside-converting ectoenzymes: Important modulators of purinergic signalling cascade. Biochim Biophys Acta, $1783(5), 673-694$.

Yu, X., Li, W., Ma, Y., Tossell, K., Harris, J. J., Harding, E. C., Ba, W., Miracca, G., Wang, D., Li, L., Guo, J., Chen, M., Li, Y., Yustos, R., Vyssotski, A. L., Burdakov, D., Yang, Q., Dong, H., Franks, N. P., \& Wisden, W. (2019). GABA and glutamate neurons in the VTA regulate sleep and wakefulness. Nat Neurosci, 22(1), 106-119.

Zhang, J. P., Xu, Q., Yuan, X. S., Cherasse, Y., Schiffmann, S. N., de Kerchove d'Exaerde, A., Qu, W.M., Urade, Y., Lazarus, M., Huang, Z.L., \& Li, R. X. (2013). Projections of nucleus accumbens adenosine A2A receptor neurons in the mouse brain and their implications in mediating sleep-wake regulation. Front Neuroanat, 7, 43.

Zimmermann, H. (2000). Extracellular metabolism of ATP and other nucleotides. Naunyn Schmiedebergs Arch Pharmacol, 362(4-5), 299-309. 
Zimmermann, H. (2006). Ectonucleotidases in the nervous system. Novartis Found Symp, 276, 113-128; discussion 128-130, 233-117, 275-181.

Zolotukhin, S., Byrne, B. J., Mason, E., Zolotukhin, I., Potter, M., Chesnut, K., Summerford, C., Samulski, R. J., \& Muzyczka, N. (1999). Recombinant adenoassociated virus purification using novel methods improves infectious titer and yield. Gene Ther, 6(6), 973-985.

Zuzuárregui, J. R. P., Bickart, K., \& Kutscher, S. J. (2018). A review of sleep disturbances following traumatic brain injury. Sleep Science and Practice, 2(1), 2. 


\section{Source}

The contents previously published in Neurochemistry International. 2019 Mar;124:256-263. (doi: 10.1016/j.neuint.2019.01.020.) are re-used in this dissertation following the guidance from Public Library of Science (or based on the approval from Elsevier after the procedure with Copyright Clearance Center) 